\begin{tabular}{|c|c|c|}
\hline WILEY 们 ONLINE LIBRARY & $\gg$ SEARCH BY & Titles \\
\hline ADVANCED SEARCH & over 5 million articles & $\begin{array}{l}\text { Keywords } \\
\text { References }\end{array}$ \\
\hline
\end{tabular}

You have full text access to this content

\title{
Urban Phosphorus Metabolism through Food Consumption
}

\section{The Case of China}

1. Gui-Lin $\mathrm{Li}^{1}$,

2. Xuemei $\mathrm{Bai}^{2}$,

3. Shen $\mathrm{Yu}^{3}$,

4. Hua Zhang ${ }^{4}$,

5. Yong-Guan $\mathrm{Zhu}^{5}$

Article first published online: 31 OCT 2011

DOI: $10.1111 / \mathrm{j} .1530-9290.2011 .00402 . x$

(C) 2011 by Yale University

Issue

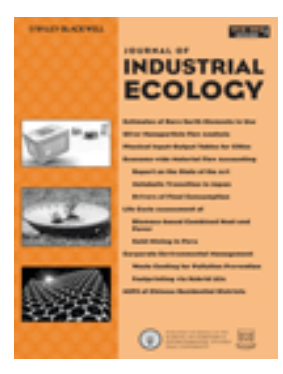

\section{Journal of Industrial Ecology}

Early View (Online Version of Record published before inclusion in an issue) (/journal/10.1111 /(ISSN)1530-9290/earlyview)

Additional Information

\section{How to Cite}

Li, G.-L., Bai, X., Yu, S., Zhang, H. and Zhu, Y.-G. (2011), Urban Phosphorus Metabolism through Food Consumption. Journal of Industrial Ecology. doi: 10.1111/j.1530-9290.2011.00402.x

\section{Author Information}

1 Chinese Academy of Sciences (IUE, CAS) in Xiamen, China 
2 Australian National University, Canberra, Australia

3 IUE, CAS in Xiamen, China

4 IUE, CAS in Xiamen, China

5 Tetra Tech, Charleston, West Virginia, USA

*Yong-Guan Zhu Key Lab of Urban Environment and Health, Institute of Urban Environment Chinese Academy of Sciences, 1799 Jimei Road, Xiamen, China, 361021, ygzhu@iue.ac.cn, http://www.iue.cas.cn

\section{Publication History}

1. Article first published online: 31 OCT 2011

- Abstract (abstract)

- Article

- References (references)

- $\underline{\text { Cited By (citedby) }}$

Get PDF (788K) (/doi/10.1111/j.1530-9290.2011.00402.x/pdf)

\section{Keywords:}

biogeochemical cycle; industrial ecology; nutrient flow; urban environment; urban food consumptio

\section{Summary}

Urbanization has significant impacts on local, regional, and global biogeochemical cycles, including through nutrient enrichment by food consumption, and especially in rapidly urbanizing countries. This article presents a time-series estimation of phosphorus $(\mathrm{P})$ metabolism through food consumption in Chinese cities and examines its relationship to income level during the period 1985-2006. Our results show that approximately $39 \%$ of the total dietary $\mathrm{P}$ inflow is exported through direct sewage discharge without treatment, $35 \%$ is exported via the output of solid human excreta, $7 \%$ is exported through sewage sludge landfill, and $19 \%$ is left within urban areas. The total inflow of dietary $\mathrm{P}$ to urban systems increases with per capita disposable income level. Furthermore, the ratio of dietary P remaining in urban systems to total dietary $\mathrm{P}$ inflow, the dietary $\mathrm{P}$ remaining in urban systems per capita, and the dietary $\mathrm{P}$ remaining per unit urban built-up area respond in an inverted $U$ shape to increases in per capita disposable income; the per capita outflow of dietary P shows a U-shaped response. These relationships may indicate that the impact of urban dietary P on urban environmental systems follows the traditional environmental Kuznets curve, while the environmental impact of urban dietary P on surrounding nonurban ecosystems initially decreases but then increases with the rising income of urban residents.

\section{Introduction}

Urbanization is one of the major social changes in human society, and the world's urban population has increased at especially high rates over the past few decades. It is projected that urban populations will 
increase most rapidly in developing countries, with an annual growth rate of $2.3 \%$ between 2000 and 2030 (UN-DESA 2008).

Rapid urbanization has changed nutrient metabolism. In the preurbanization period, biogeochemical cycles were closed or approximately closed loops dominated by natural processes with only slight disturbance from agricultural activities (Chen et al. 2008). Ecosystems did not rely much on external inputs and biomass was utilized conservatively. During the growth of urbanization, however, these closed biogeochemical cycles were gradually impacted by the unprecedented intensification of human disturbance through individual, collective, and institutional behaviors (Pickett et al. 2001; Bai 2007), such as population densification, increased production and consumption activities, impervious surface proliferation, and engineered water flow paths (Kaye et al. 2006). In addition, nutrient cycling in urban areas was influenced by changing food consumption patterns, investment in environmental infrastructures, and so on. These urban factors are far different from those in agricultural ecosystems and make nutrient metabolism in urban ecosystems increasingly dominant in biogeochemical cycling (Kaye et al. 2006).

Urban metabolism is a concept that likens a city to an organism, by which it depends on external inputs of water, energy, and food to sustain itself while discharging waste and pollutants (Wolman 1965; Bai 2007; Kennedy et al. 2007). The environmental impacts of this metabolism can remain within the city or extend to regional and global scales (Bai 2003, 2007). Urban nutrient metabolism is the nutrient flow into and out of the urban environment during the urban metabolism process. Nutrient metabolism, through food and other raw material flows, can result in the irregular accumulation of nutrients in urban areas and negatively influence their sustainability (Kennedy et al. 2007; Grimm et al. 2008). Therefore, it is important to understand the storage processes and fluxes of nutrients in urban metabolisms. Many studies on urban nutrient metabolism have been undertaken based on the mass balance within a defined urban boundary (Newcombe 1977; Nilson 1995; Bjorklund et al. 1999; Farge et al. 2001; Forkes, 2007; Neset et al. 2008). For example, Farge and colleagues (2001) estimated the urban nutrient flow in the whole Bangkok province based on food consumption data, and monitored concentrations of nitrogen $(\mathrm{N})$ and phosphorus $(\mathrm{P})$ in the inlets and outlets of main rivers in the region. Neset and colleagues (2008) quantified the $\mathrm{P}$ metabolism for food production and consumption in Linkoping, Sweden, for the years 1870-2000, as well as its influences on the regional ecosystem. However, few studies have described both the process of nutrient accumulation in cities through various pathways and the relationship of urban nutrient metabolism with urbanization and income growth. Such a study is particularly relevant in China, where urbanization is occurring very rapidly.

In urban nutrient metabolism, $\mathrm{P}$ is of particular importance due to its global scarcity, its close relationship to food security (Cordell et al. 2009), and its potential environmental impacts on urban and periurban ecosystems. The migration of large populations into cities suggests food consumption is increasingly concentrated in urban areas. As a result, more nutrients, including $\mathrm{P}$, are being imported into urban areas through food consumption. While the absolute amount of $\mathrm{P}$ inflow to urban areas is small compared to $\mathrm{P}$ storage in agricultural soil and outflow into oceans (Liu et al. 2008), the environmental consequences can be significant, considering that urban areas occupy less than $3 \%$ of the global terrestrial area (Grimm et al. 2008). The increase in $\mathrm{P}$ inflow to urban areas is a significant factor contributing to eutrophication in urban soil and aquatic systems in both developing and developed countries or regions, such as China 
(Zhang et al. 2007), Sweden (Decker et al. 2000), and Bangkok (Farge et al. 2001).

The metabolism of $\mathrm{P}$ through food consumption has particular relevance for China considering its rapid urbanization, economic development and associated dietary structure changes, and the environmental issues in urban and periurban areas over the last three decades. The urban population (urbanization level) in China rose from 24\% in 1985 to $45 \%$ in 2007 (figure 1). Urban dietary consumption accounted for 61\% of the national total in 2007. While there are some national-level analyses on the $\mathrm{P}$ cycle through agricultural systems in China (Liu and Chen 2006; Liu et al. 2007; Chen et al. 2008), little is known about $\mathrm{P}$ flow through Chinese urban areas via food consumption.

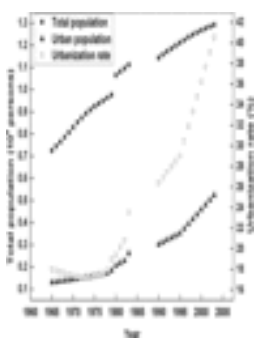

Figure 1. Trends in urbanization and population rates in China.

Download figure to PowerPoint (/doi/10.1111 /j.1530-9290.2011.00402.x /figure.pptx?figureAssetHref=image n/JIEC 402 fl.gif)

In this study, urban P metabolism in China is analyzed from the perspective of food consumption at a national scale between 1985 and 2006 (excluding Hong Kong, Macao, and Taiwan due to data limitations). Urban dietary P metabolism is defined here as the P flow into and out of urban systems through food consumption by urban residents. The boundary of the "urban system" in this study is defined as the urban built-up area published by either the China Statistical Yearbook (NBSC, various years [1985-2008]). The study covers all prefecture-level cities published in the China Statistical Yearbook, and does not include county-level cities in China. The purpose of the study is threefold: (1) to estimate the amounts of and trends in the input and output of $\mathrm{P}$ through food consumption in Chinese cities; (2) to identify the amounts and accumulation of dietary P that remains within urban systems; and (3) to analyze through panel analysis how these various components of urban P metabolism relate to urban development and economic growth. Insights gained from this study have implications for urban development and planning as well as resource and environmental management. They also contribute toward an understanding of the changing metabolic behavior of cities over time for China and other developing countries experiencing rapid urbanization.

\section{Method and Data}

\section{Method}

The flow of dietary P into and out of urban areas was analyzed based on mass balance. Figure 2 shows the conceptual model and system boundaries of our analysis, including dietary P inflow to urban systems through urban household consumption and outflow from urban systems through waste disposal. As stated above, the boundary of the "urban system" in this study is defined as the urban built-up area. We have only included the P flow from edible parts of food consumed in urban areas, because (1) the inedible parts of food (such as decayed vegetable leaves, inedible roots, and fish and meat bones) are discarded and 
transported out of the city as solid waste, and thus the P in these parts only forms a throughput; (2) the food consumption data used in this study are based on net daily intake; and (3) neither the quantities of inedible food solid waste nor the $\mathrm{P}$ concentration in food solid waste was available during our study period. This does not affect our estimate of the P accumulation in urban areas through household food consumption at the macro scale or its dynamic trend over time.

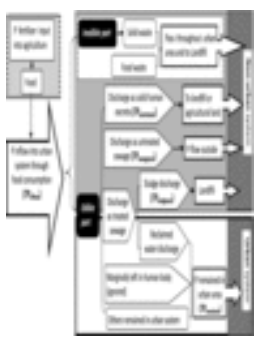

Figure 2. Conceptual model of urban dietary phosphorus (P) flow into and out of urban areas. For the mass balance calculation and definitions of variables, see the Method section of this article.

Download figure to PowerPoint (/doi/10.1111 /j.1530-9290.2011.00402.x /figure.pptx?figureAssetHref=image_n/JIEC_402_f2.gif)

According to figure 2, the following equations were established to determine the amount of urban dietary $P$ flow into and out of the urban system:

$$
\begin{aligned}
T P_{\text {inflow }}= & \left(T P_{\text {sewagecut }}+T P_{\text {sludgeout }}\right) \\
& \times f+T P_{\text {excretacut }}+T P_{\text {remained }},
\end{aligned}
$$

where $T P$ inflow is the dietary $\mathrm{P}$ consumed by urban households, $T P$ sewageout is the dietary $\mathrm{P}$ directly discharged and $T P$ sludgeout is the dietary $\mathrm{P}$ export via municipal sludge, $f$ is the fraction of the dietary $\mathrm{P}$ from household sewage in municipal sewage drainage systems, $T P$ excretaout is the dietary $\mathrm{P}$ export via solid human excreta collected by environment and hygiene services, and $T P$ remained is the dietary $\mathrm{P}$ eventually remaining in the urban system. A constant fraction of 50\% was used (Yang et al. 2006) for $f$.

$$
\text { - } T P_{\text {inflow }}=N_{\text {up }} \times P_{\text {cd }} \times 365 \text {, }
$$

where $N_{\text {up }}$ is the total urban population and $P_{\mathrm{cd}}$ is the per capita daily dietary $\mathrm{P}$ consumed by urban households, which is calculated as

$$
P_{\mathrm{cd}}=\sum\left(Q_{\mathrm{cd}} \times C_{\mathrm{Pfood}}\right)
$$

Here, $Q_{\mathrm{cd}}$ is the per capita daily consumption of a certain food group by urban households, and $C_{\mathrm{Pfood}}$ is the $\mathrm{P}$ concentration in edible parts of a certain food group.

$$
\text { - } T P_{\text {sewageout }}=D \times(1-R) \times C_{\text {untrested }} \text {, }
$$

where $D$ is the discharge volume of urban household sewage per annum, $R$ is the urban household sewage treatment rate per annum, and $C$ untreated is the $\mathrm{P}$ concentration in the directly discharged urban household sewage without treatment. 
where $C_{\text {allowed }}$ is the maximal $\mathrm{P}$ concentration allowed in discharged reclaimed water after treatment and $C_{\text {untreated }}$ is the $\mathrm{P}$ concentration in untreated discharge.

$$
\text { - } T P_{\text {excretsout }}=M \times C_{\text {Pexcreta }} \text {, }
$$

where $M$ is the annual export of solid human excreta out of urban systems via non-sewage pathways and $C_{\text {Pexcreta }}$ is the concentration of $\mathrm{P}$ in solid human excreta.

In urban China, household sewage and industrial wastewater share the same municipal sewer drainage system. About $50 \%$ of the $\mathrm{P}$ contained in municipal sewage in China is from household sources and $50 \%$ is from industrial sources (Yang et al. 2006). Part of the municipal sewage is piped for treatment, and the treated water is either reclaimed to irrigate urban green areas and flush streets or it is piped into urban water bodies. Thus this part of $\mathrm{P}$ in reclaimed sewage reenters and largely remains within our defined urban system boundary. Sludge from the sewage treatment leaves the urban system and is usually landfilled outside of the city, with a very small part composted and applied to agriculture. Untreated sewage is piped directly into natural systems outside of cities. Part of the human excreta (solids) is collected separately and transported out of urban systems by environment and hygiene services.

A global sensitivity analysis was conducted based on the Extended Fourier Amplitude Sensitivity Test (EFAST) to determine the sensitivity of the total $P$ remaining in urban systems ( $T P$ remained) to changes in the parameters (see equation (1) in figure 2). The main idea of EFAST-based sensitivity analysis is to evaluate how the variance of an input variable $\left(\operatorname{Var}\left(x_{\mathrm{i}}\right)\right)$ contributes to the variance of model outputs $(\operatorname{Var}(Y))$. This ratio is the total sensitivity index, and lies within a range of 0 to 1 . $\operatorname{Var}\left(x_{i}\right)$ can be decomposed into two parts: the contribution to variance of the variable itself (main effect), and the interaction of this variable and other variables involved in the model with the total variance of model output $(\operatorname{Var}(Y))$ (joint effect). The main effect defines the first-order sensitivity index, reflecting the contribution of this variable. The correlation between input variables was considered closely in the sensitivity analysis ( $\mathrm{Xu}$ and Gertner 2008, 2011) using the toolbox UASA (v.1.1) (downloadable from https://sites.google.com/site/xuchongang/uasatoolbox (https://sites.google.com/site/xuchongang /uasatoolbox)). We adopted the data from 2006 to conduct the sensitivity analysis for all parameters, with two assumptions: (1) all input parameters follow uniform distributions with $\pm 20 \%$ data disturbance; (2) parameters are correlated with each other.

\section{Data}

The data on urban dietary P flow were obtained from various sources (table 1) and subjected to rigorous crosschecking before analysis. The key datasets are described in table 1.

\section{Table 1. Detailed description of key datasets}




\section{Data}

$N_{\text {up }}$

$Q_{\text {cd }}$

Urban

population

Per capita daily consumption of a certain food group by urban household in China $^{\mathbf{A}}$
Unit

10,000 persons

g edible part food/capita/day

Source

Note

NBSC

1985-2008

Zhai et al. $\underline{2005}$

Until 1992, $Q_{\text {cd }}$ was calculated as the arithmetic mean of daily urban consumption per capita of each kind of food separately in 1982 and 1992. After 1992, $Q_{\text {cd }}$ was represented by the value of urban consumption per capita of each kind of food in 2002.

$C_{\text {Pfood }}$

$\begin{array}{ll}\text { P concentration } & \mathrm{gP} / 100 \mathrm{~g} \\ \text { in the edible } & \text { edible part } \\ \text { part of a certain } & \\ \text { food group } & \\ \text { commonly } & \\ \text { consumed by } \\ \text { Chinese urban } \\ \text { households }\end{array}$

Wang 1991

Arithmetic mean of $P$ concentration in edible part of each kind of food in each group from 1986 to 1992

INFS, China CDC 2005

Arithmetic mean of $P$ concentration in edible part of each kind of food in each group from 1993 to 2006

Note: $\mathrm{g}$ edible part food/capita/day = grams of edible food parts per capita per day; g P/100 g edible part $=$ grams of $\mathrm{P}$ per 100 grams of edible food parts; $\mathrm{mg} / \mathrm{L}=$ milligrams per liter; $\mathrm{kg}=$ kilograms; $\mathrm{km}^{2}=$ square kilometers.

${ }^{\mathrm{A}}$ The data are from 21,103 persons from 10,027 households in urban areas of 31 provinces in China. Percent of population with age $>18$ years old is more than $77 \%$. 
D

$R$

$C_{\text {untreated }}$

\section{$C_{\text {allowed }}$}

\section{Data}

\section{Unit}

million tonnes discharge volume of urban household sewage household sewage treatment rate
Source

NBSC

1985-2008 percentage

$\frac{\text { CMEP }}{(1995-2008)}$

The $R$ values from 1985 to 1994 were calculated according to the China Statistical Yearbook on Environment

BMEDI

$\underline{2006}$
P concentration in untreated urban household sewage (calculated as P)

$\mathrm{mg} / \mathrm{L}$

$\mathrm{mg} / \mathrm{L}$

concentration

allowed in

reclaimed

discharge water

after treatment

(calculated as

P)

Amount of

million tonnes

CMEP 2002

solid human

excreta

Note: g edible part food/capita/day = grams of edible food parts per capita per day; $\mathrm{g}$ P/100 g edible part $=$ grams of $\mathrm{P}$ per 100 grams of edible food parts; $\mathrm{mg} / \mathrm{L}=$ milligrams per liter; $\mathrm{kg}=$ kilograms; $\mathrm{km}^{2}=$ square kilometers.

${ }^{\mathrm{A}}$ The data are from 21,103 persons from 10,027 households in urban areas of 31 provinces in China. Percent of population with age $>18$ years old is more than $77 \%$. 


\section{Data}

$C_{\text {Pexcreta }}$

f

excreta
Unit

percentage

concentration in

solid human

The fraction of

the dietary $P$

percentage

amount from

household

sewage in the

municipal

sewage

drainage system

Fertilizer

application

$\left(\mathrm{P}_{2} \mathrm{O}_{5}\right)$

Urban built-up $\quad \mathrm{km}^{2}$

area

Arable land

area
Source

Note
Lv 2004;

Mnkeni and

Austin 2009

Yang et al.

$\underline{2006}$
NBSC

1985-2008

NBSC

1985-2008

NBSC

1985-1996
Data from 1997 to

2006 were from

Communiqué on

Land and Resources

of China by the

Ministry of Land

and Resources, China

Note: $\mathrm{g}$ edible part food/capita/day $=$ grams of edible food parts per capita per day; $\mathrm{g} \mathrm{P} / 100 \mathrm{~g}$ edible part $=$ grams of $\mathrm{P}$ per 100 grams of edible food parts; $\mathrm{mg} / \mathrm{L}=$ milligrams per liter; $\mathrm{kg}=$ kilograms; $\mathrm{km}^{2}=$ square kilometers.

${ }^{A}$ The data are from 21,103 persons from 10,027 households in urban areas of 31 provinces in China. Percent of population with age $>18$ years old is more than $77 \%$.

In this study, a total of 201 types of food commonly consumed by urban households in China were analyzed. These 201 types were classified into nine groups. The food groups and corresponding number of food types in each group are cereals (14 types), potato tubers (7), vegetables (40), fruits (26), animal 
meats (17), poultry meats (47), milk products (9), poultry eggs (7), and aquatic products (34).

The data on dietary consumption by urban households $\left(Q_{\mathrm{cd}}\right)$ were obtained from two sources: the National Bureau of Statistics of China (NBSC) and the national nutrition survey. The mean annual dietary consumption (grain equivalents) by urban households is 323 kilograms per capita per year (kg/capita/yr) calculated from the former source (NBSC 2003), and $404 \mathrm{~kg} /$ capita/yr from the latter (Zhai et al. 2005). ${ }^{1}$ Grain consumption in the former source is defined by the mass of processed grains $(0.85 \times$ mass of unprocessed grains) consumed (Feng and Shi 2006). Thus the two results are actually similar. The data from the national nutrition survey were selected because they are collected in a more systematic manner at the national scale than the data from the NBSC (Liu et al. 2007). Nationwide nutrition surveys were conducted in 1959, 1982, 1992, and 2002, organized by the Ministry of Health and Ministry of Science and Technology with help from the NBSC. The results on daily dietary consumption for urban households in 1982, 1992, and 2002 were published in an article by Zhai and colleagues (2005) and used in this study.

P concentration ( $C_{\text {Pfood }}$ ) in the edible parts of plant-based food has changed over the 1985-2006 period as fertilizer application has shifted from chiefly livestock manure to mainly chemical fertilizer. This modified fertilization practice affects the availability of $\mathrm{P}$ in the soil for crop uptake, and hence produces different P concentrations in the edible parts of food (Mohanty et al. 2006; Zhou et al. 2009). The mean P concentration in the edible parts of food is therefore represented for the 1985-1992 period by the measured value in 1991, and for the 1993-2006 period by the measured value in 2004. These values were obtained from the Institute of Nutrition and Food Safety, Chinese Center for Disease Control and Prevention (Wang 1991; INFS, China CDC 2005). The data on chemical P fertilizer application, cultivated land area, and urban built-up area at the national level were obtained from the China Statistical Yearbook in various years.

Data for urban household sewage discharge $(D)$ and sewage treatment rate $(R)$ are from the China Statistical Yearbook (NBSC, various years [1985-2008]) or Statistic Communique on Environment in China (CMEP, various years [1985-2008]) (figure 3). The period from 1986 to 2006 was investigated because no data were recorded on urban household sewage before 1985 . The year 1992 is set as a threshold based on the facts that (1) 1992 is usually regarded as a dividing line when analyzing China's economy and socioeconomic development (Wong 1998; Xie et al. 2005), and (2) data on per capita daily food consumption were only available in the years 1982, 1992, and 2002. The mean value of daily urban dietary consumption per capita in 1982 and 1992 was used to represent the period 1985-1992. The survey data in 2002 were used to represent the mean value during the period 1993-2006 (table 1).

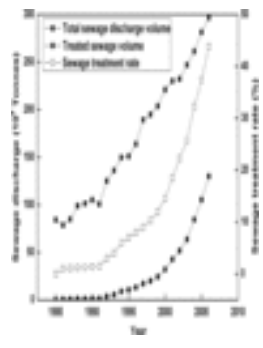

Figure 3. Changes of urban household sewage discharge and treatment rates, 1985-2006.

Download figure to PowerPoint (/doi/10.1111

j.1530-9290.2011.00402.x

/figure.pptx?figure AssetHref=image_n/JIEC_402_f3.gif)

The $\mathrm{P}$ concentration in China's urban household sewage (calculated as P) varies significantly, from a low 
of 4 milligrams per liter $(\mathrm{mg} / \mathrm{L})$ to a high of $16 \mathrm{mg} / \mathrm{L}$, with a mean value of $8 \mathrm{mg} / \mathrm{L}$ (BMEDI 2006). ${ }^{2}$ The mean value of $8 \mathrm{mg} / \mathrm{L}$ was selected to represent the mean $P$ concentration in China's urban household sewage $(C$ untreated). The highest $\mathrm{P}$ concentration permitted in discharged sewage after treatment $(C$ allowed $)$ is $1 \mathrm{mg} / \mathrm{L}$ according to China's Standard on Sewage Treatment and Discharge (CMEP 2002).

Part of the human excreta (solids) is collected and transported out of cities by municipal environment services. The remaining excreta enters the municipal sewer piping system. The data on annual export of human excreta are from the China Urban Construction Statistical Yearbook (MOC 2007). The P concentration in solid human excreta is set, according to the literature, at $0.4 \%$ ( $\underline{\mathrm{Lv} 1994 ;}$ Mnkeni et al. $\underline{2009)}$.

\section{Results and Discussion}

\section{Dietary P Consumption by Urban Households}

The data on P concentration in the 201 types of food commonly consumed by urban households in China were analyzed. On average, 3.7 grams diphosphorus pentoxide per capita per day $\left(\mathrm{g} \mathrm{P}_{2} \mathrm{O}_{5} /\right.$ capita/day) was imported into urban areas through food consumption between 1985 and 1992. ${ }^{3}$ The number decreased slightly to $3.5 \mathrm{~g} \mathrm{P}_{2} \mathrm{O}_{5}$ /capita/day between 1993 and 2006 (table 2), which is mainly due to changes in the food consumption structure according to the variance analysis of $\Delta C$ Pfood and $\Delta Q_{\mathrm{cd}}$. Plant-derived dietary $\mathrm{P}$ per capita per day decreased from $2.8 \mathrm{~g} \mathrm{P}_{2} \mathrm{O}_{5}$ (1985-1992) to $1.5 \mathrm{~g} \mathrm{P}_{2} \mathrm{O}_{5}$ (1993-2006). In contrast, animal-derived dietary $\mathrm{P}$ per capita per day increased from $0.9 \mathrm{~g} \mathrm{P}_{2} \mathrm{O}_{5}$ to $1.9 \mathrm{~g}$ $\mathrm{P}_{2} \mathrm{O}_{5}$ (table 2). Our results are comparable to the import of $3.9 \mathrm{~g} \mathrm{P}_{2} \mathrm{O}_{5} /$ capita/day through food consumption in Hong Kong in 1971, but far lower than that in 1997, which was $8.6 \mathrm{~g} \mathrm{P}_{2} \mathrm{O} 5$ /capita/day (Warren-Rhodes and Koenig 2001). Food consumption per capita per day in Hong Kong in 1997 (2,092 g) is nearly twofold higher than the mean value in China from 1993 to 2006 (1,107 g) (table 2), which may explain why the P import in Hong Kong in 1997 is much higher than that in China between 1993 and 2006. The dietary $P$ consumption by urban households and subsequent total inflow of $P$ into cities in China may be at a relatively low level, and may increase significantly in the future along with rising living standards and associated changes in dietary structure. This hypothesis can be supported to a degree by the following analysis of the relationship between the behavior of urban dietary P metabolism and per capita disposable income of urban residents (figure 6A).

\section{Table 2. Phosphorus (P) concentration and consumption of each food group}

\begin{tabular}{lccc} 
Food & $\mathrm{C}_{\mathrm{Pfood}}\left(\mathrm{g} \mathrm{P}_{2} \mathrm{O}_{5} / 100 \mathrm{~g}\right.$ & & \\
groups & edible part $)$ & $Q_{c d}(\mathrm{~g} /$ capita/day $)$ & $\mathrm{P}_{c d}\left(\mathrm{~g} \mathrm{P}_{2} \mathrm{O}_{5} / \mathrm{ca}_{1}\right.$ \\
\hline
\end{tabular}




\section{$\begin{array}{llllll}1985-1992 & 1993-2006 & 1985-1992 & 1993-2006 & 1985-1992 & 19\end{array}$}

Cereals

0.48

0.33

432

357

2.07

Potato

0.08

0.14

56

31

0.04

tubers

Vegetables

0.22

0.10

311

260

0.68

Fruits

0.05

0.05

74

74

0.04

Animal

0.47

0.40

61

62

0.29

meat

Poultry

0.37

0.35

20

24

0.08

meat

Milk

0.55

0.82

23

74

0.13

products

Poultry

0.47

0.41

23

193

0.11

eggs

Fishery

0.74

0.59

330

36

0.24

products

Sum

Note: $C_{\text {Pfood }}=$ the $\mathrm{P}$ concentration in edible parts of a certain food group; ( consumption of a certain food group by urban households; $P_{\mathrm{cd}}=$ the per cap by urban households; $\mathrm{g} \mathrm{P}_{2} \mathrm{O}_{5} / 100$ g edible part = grams diphosphorus pentc edible food parts; g/capita/day = grams per capita per day; $\mathrm{g} \mathrm{P}_{2} \mathrm{O}_{5} /$ capita/da pentoxide per capita per day; n.a. = not available.

${ }^{A}$ Calculated according to the food consumption in Hong Kong in 1997 (kg/ and Koenig 2001). The total of other consumed food items, including oils al sweeteners, stimulants and spices, is $545 \mathrm{~g} /$ capita/day, which is not shown i1 $\mathrm{B}$ Includes animal and poultry meat.

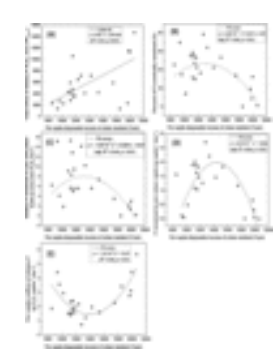

Figure 6. Relationship between per capita disposable income of urban residents and indicators related to dietary phosphorus $(\mathrm{P})$ flow in provincial capital cities of China (example in 2006). $\mathrm{P}_{2} \mathrm{O}_{5}=$ diphosphorus pentoxide; ton $=$ metric tons; $\mathrm{km}^{-2}=$ square kilometers; Yuan $=$ Chinese yuan (1 Chinese yuan $[\mathrm{RMB}] \approx 0.127$ USD in 2006). 


\section{Mass Balance of Dietarangad}

/figure.pptx?figureAssetHref=image n/JIEC 402 f6.gif)

The yearly change of dietary $\mathrm{P}$ inflow to and outflow from urban areas of China is presented in figure 4. The annual inflow of dietary $\mathrm{P}$ (calculated as $\mathrm{P}_{2} \mathrm{O}_{5}$ hereafter) increased from $218 \times 10^{3}$ tonnes in 1985 to $491 \times 10^{3}$ tonnes in 2006 (figure 4A). Total inflow of dietary P to urban areas between 1985 and 2006 was $7,225 \times 10^{3}$ tonnes. The reasons for the increase in the $\mathrm{P}$ inflow include increases in food consumption, changes in dietary structure, and urban population growth. Another influence may be the growth in the number of cities in China, which increased from 162 in 1985 to 283 in 2006. The outflow of dietary $\mathrm{P}$ is through three pathways: (1) export through wastewater discharge without treatment (TP sewageout), (2) through sewage sludge (TP sludgeout), and (3) through solid human excreta (TP excretaout) (figure 4B). As a whole, the cumulative export of urban dietary P was 5,867 × $10^{3}$ tonnes (1985-2006), suggesting that $19 \%$ of total dietary $\mathrm{P}$ inflow remained in urban areas during this period. Thus the consumption of 1 kilogram $(\mathrm{kg})$ of dietary $\mathrm{P}$ in an urban area implies that there will be $0.2 \mathrm{~kg}$ dietary $\mathrm{P}$ remaining in the urban area, with $0.8 \mathrm{~kg}$ dietary $\mathrm{P}$ transported out of the urban system.

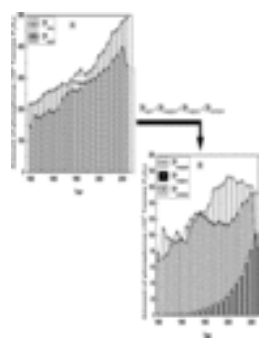

Figure 4. (A) Annual dietary phosphorus (P) imported into and exported out of urban areas. (B) Annual export of dietary $\mathrm{P}$ through wastewater discharge without treatment, solid human excreta, and sewage sludge. For definitions of variables, see the Method section of this article. $\mathrm{P}_{2} \mathrm{O}_{5}=$ diphosphorus pentoxide.

Download figure to PowerPoint (/doi/10.1111 /j.1530-9290.2011.00402.x /figure.pptx?figureAssetHref=image_n/JIEC_402_f4.gif)

The dietary $\mathrm{P}$ eventually remaining in urban areas was $72 \times 10^{3}$ tonnes in 1985 and $149 \times 10^{3}$ tonnes in 2006. In total, about $1,358 \times 10^{3}$ tonnes of dietary $\mathrm{P}$ from urban household consumption accumulated in urban areas over the 1985-2006 period. This considerable accumulation of dietary $\mathrm{P}$ in urban areas is partly due to poor environmental management policies and practices and a focus on rapid local economic growth. The biogeochemistry of elements in urban areas is strongly influenced by human activities and is more complex than the biogeochemistry in agricultural contexts. The partitioning models for elements in agricultural ecosystems are not suitable for urban environments (Kaye et al. 2006), therefore it is hard to quantify the accumulation of dietary P into various urban environmental media such as urban soil, urban water bodies, and so on.

\section{Temporal Trends of Dietary P Inflow Intensity}

Figure 5 shows trends in the load of urban dietary P inflow, the load of urban dietary P remaining in cities, and the total load of chemical $P$ fertilizer application. The inflow intensity (load of imported $P$ per unit urban area) of urban dietary $\mathrm{P}$ is two to three times higher than that of chemical $\mathrm{P}$ fertilizer application on agricultural land between 1985 and 2006, suggesting that the urban ecosystem is heavily burdened with a 
considerable inflow of dietary P. For instance, in 2006, the total dietary P inflow into cities $\left(491 \times 10^{3}\right.$ tonnes) was $6 \%$ of the $\mathrm{P}$ from fertilizer consumption $\left(7,695 \times 10^{3}\right.$ tonnes $)$; in contrast, urban built-up area constituted only $2 \%$ of the area of agricultural land. These data reinforce the previous findings that urban ecosystems have a much higher intensity of $\mathrm{P}$ assimilation than natural (agricultural) ecosystems (Pickett et al. 2001; Klee and Graedel 2004; Kaye et al. 2006).

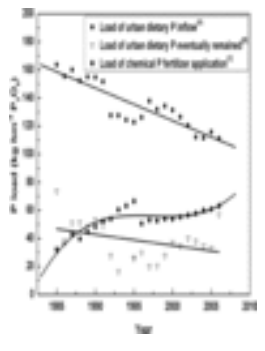

Figure 5. Per unit area load of urban dietary phosphorus (P) on urban areas compared to chemical P fertilizer applied on agricultural land. $\mathrm{kg} \mathrm{hm}^{-2} \mathrm{P}_{2} \mathrm{O}_{5}=$ the weight $(\mathrm{kg})$ of $\mathrm{P}_{2} \mathrm{O}_{5}$ distributed on unit area of urban/agricultural land

Download figure to PowerPoint (/doi/10.1111

j.1530-9290.2011.00402.x

/figure.pptx?figureAssetHref=image n/JIEC 402 f5.gif)

Nevertheless, the inflow intensity of urban dietary P tended to decline over the 1985-2006 period (figure 5). The explanation for this is that the urban area expanded faster than the increase in urban population over the past 20 years (Liu et al. 2005; Li et al. 2007).

\section{Relationship between Urban Dietary P Metabolism and Income Growth}

Figure 6A indicates that the total inflow of dietary $\mathrm{P}$ into urban systems increases with per capita disposable income level. Furthermore, the following figures respond in an inverted U-shape as per capita disposable income of urban residents rises: the ratio of dietary $\mathrm{P}$ remaining in urban systems to total $\mathrm{P}$ inflow, the dietary $\mathrm{P}$ remaining per unit of urban built-up area, and the $\mathrm{P}$ remaining in urban systems per capita (figure 6B-D). The per capita outflow of dietary P instead shows a U-shaped response (figure 6E). The relationships suggest nonlinearity in the behavior of urban dietary P metabolism and economic growth, following theories of the environmental Kuznets curve. Bai and Imura (2000) discuss in detail the changing patterns of major urban environmental issues as they relate to economic growth, and suggest that urban environmental quality often follows an inverted $U$ shape during industrialization and economic evolution from poverty to greater wealth. For the urban P metabolism, the underlying mechanism could be increased investment in sewage treatment facilities as per capita disposable income increases. Our analysis reveals that the environmental impact of urban dietary $\mathrm{P}$ on urban ecosystems follows the traditional environmental Kuznets curve (figure 6B-D), while the environmental impact of urban dietary P on surrounding nonurban ecosystems initially decreases, but increases with rising per capita income of the urban residents (figure 6E). This echoes earlier literature that finds that as cities get richer, their environmental burdens tend to shift to outside their boundaries (Bai 2002; Satterthwaite 2003).

\section{Sensitivity Analysis}


The global sensitivity analysis was conducted on all variables ( $N_{\text {up }}, D, R, M, f, C_{\text {allowed }}, C_{\text {untreated, }}$, $\left.C_{\text {Pexcreta, and the variable }} Q_{\operatorname{Pcd}}\left(Q_{\mathrm{cd}} \times C_{\text {Pfood }}\right)\right)$. Figure 7A gives the total and the first-order sensitivity indices of input variables to the model output. Figure 7B shows the relative contribution of each input variable to the total sensitivity of model results. It can be seen that the urban population number $\left(N_{\text {up }}\right)$, wastewater discharge $(D)$, and wastewater treatment rate $(R)$ are the most sensitive to total dietary $\mathrm{P}$ remaining in urban systems ( $T P$ remained), with a contribution of $25 \%$ each. Solid human excreta $(M), f$, and $C_{\text {allowed }}$ are moderately sensitive. $C_{\text {untreated, }} C_{\text {Pexcreta }}$ and $Q_{\operatorname{Pcd}}\left(Q_{\mathrm{cd}} \times C_{\text {Pfood }}\right)$ are least sensitive to the model output. For example, daily urban per capita dietary $P$ consumption $\left(Q_{\operatorname{Pcd}}\left(Q_{c d} \times C_{P f o o d}\right)\right)$ is considered constant (although respectively different) in the periods 1986-1992 and 1993-2006. This result is supported by the fact that the daily per capita dietary $\mathrm{P}$ consumption has been relatively constant during past 50 years in both the United States (National Research Council 1989) and Sweden (Neset et al. 2008), therefore treatment of daily per capita dietary P consumption as a constant in our calculations does not drastically affect the results.

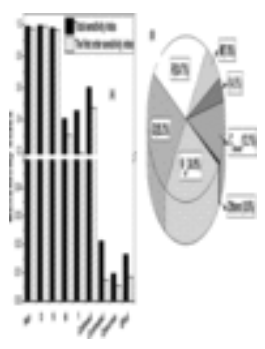

\author{
Figure 7. Sensitivity indices of the parameters (A) and \\ their relative contribution to the total sensitivity of model \\ output (B). For definitions of variables, see the Method \\ section of this article. $Q_{P c d}=$ the amount of $P$ consumed \\ per day. \\ Download figure to PowerPoint (/doi/10.1111 \\ /j.1530-9290.2011.00402.x
} /figure.pptx?figureAssetHref=image_n/JIEC_402_f7.gif)

Besides the uncertainties produced by the above variables, uncertainty in the model output may be caused by other factors that are difficult or even impossible to measure. For example, food consumed away from home (FAFH), such as from restaurants, has been omitted in our calculation. According to the nationwide nutrition survey in China, $91.5 \%$ of urban households tend to consume three meals per day at home (Ma et al. 2006). On the other hand, FAFH is difficult to investigate on a national scale. Thus only food consumed at home was considered in this study. However, future research is needed to estimate this proportion and to reduce the resultant error.

In our calculations we assumed that total $\mathrm{P}$ in reclaimed water remained in urban systems. In fact, some of the reclaimed water from treated urban household sewage is used for toilet flushing, and thus the P reenters the sewage system. Likewise, the portion of $\mathrm{P}$ in reclaimed water used for irrigating urban areas may reenter the municipal water treatment works. However, given that this subcycle does not involve dietary $\mathrm{P}$ input and that reclaimed water can be reused for sanitation after treatment, we assume that this $\mathrm{P}$ will reenter the urban system.

\title{
Concluding Remarks
}

Based on mass balance calculations, the pathways and temporal variations of dietary $\mathrm{P}$ consumed by 
urban populations in China from 1986 to 2006 were analyzed. The relationships between these pathways and income level were also examined. Our results indicate that the load of total dietary $\mathrm{P}$ inflow on per unit urban area is two to three times higher than that of chemical $\mathrm{P}$ fertilizer application on per unit agricultural land area in China. For each $1 \mathrm{~kg}$ of dietary $\mathrm{P}$ consumed, $0.2 \mathrm{~kg}$ remain in urban areas, with $0.8 \mathrm{~kg}$ exported out of urban areas. The accelerating rate of urbanization in the coming decades means that more dietary $\mathrm{P}$ will be imported into urban areas because of both growing urban populations and increases in per capita $\mathrm{P}$ consumption. These changes will exacerbate a series of environmental problems.

The following figures respond in an inverted U-shape to increases in per capita disposable income of urban residents: the ratio of dietary $\mathrm{P}$ remaining in urban systems to total dietary $\mathrm{P}$ inflow, $\mathrm{P}$ remaining in urban systems per capita, and dietary P remaining per unit urban built-up area. However, the per capita outflow of dietary P shows a U-shaped response. These results may indicate that the environmental impacts of urban dietary $\mathrm{P}$ on urban ecosystems follow the traditional environmental Kuznets curve, while the environmental impacts of urban dietary $\mathrm{P}$ on surrounding nonurban ecosystems initially decrease but then increase with rising income.

Our results suggest several policy implications. The growing concentration of $\mathrm{P}$ in cities suggests the importance of looking at cities as potential sources for recovering $\mathrm{P}$, which will in turn address the environmental pollution issues caused by the dietary $\mathrm{P}$ outflow from cities. Our results show that as cities become richer, the inner-city environmental quality tends to improve, but environmental burdens tend to shift outside the urban boundaries. This suggests a need to adopt a holistic systems approach to urban and regional environmental management.

\section{Acknowledgement}

Great thanks are due to the anonymous reviewers for their critical comments and suggestions. The authors are also grateful to relevant experts and government officers for their provision of data and suggestions on the model. Thanks also to Dr. Xu and the author of Simlab for their help in the global sensitivity analysis of correlated variables. This study was supported by the National Science Foundation of China (40901263), Sino-British S\&T Cooperation project (2009DFB90120), and the "Hundred Talents Program" of the Chinese Academy of Sciences (07i4271a10).

\section{Notes}

1 One kilogram $(\mathrm{kg}, \mathrm{SI}) \approx 2.204$ pounds $(\mathrm{lb})$.

2 One milligram $(\mathrm{mg}, \mathrm{SI})=10^{-3}$ grams $(\mathrm{g}) \approx 3.53 \times 10^{-5}$ ounces $(\mathrm{oz})$; one liter $(\mathrm{L})=0.001$ cubic meters $\left(\mathrm{m}^{3}, \mathrm{SI}\right) \approx 0.264$ gallons $($ gal $)$.

3 One gram $(\mathrm{g})=10^{-3}$ kilograms $(\mathrm{kg}, \mathrm{SI}) \approx 0.035$ ounces $(\mathrm{oz})$.

\section{References}

Bai, X. M. 2002. Industrial relocation in Asia: A sound environmental management strategy? Environment 44(5): 8-21. 
CrossRef (/resolve/reference/XREF?id=10.1080/00139150209605786), Web of Scienc Times Cited: 10 (/resolve/reference/ISI?id=000175754800003)

(?url ver $=$ Z39.88-2004\&

rft val fmt=info $\% 3$ Aofi $\% 2 \mathrm{Ffmt} \% 3 \mathrm{Akev} \% 3 \mathrm{Amtx} \% 3 \mathrm{Ajournal} \& \mathrm{rft} . \mathrm{genre}=$ article $\&$ rft.jtitle=Environment\&rft.atitle=Industrial\%20relocation $\% 20 \mathrm{in} \% 20$ Asia $\% 3 \mathrm{~A} \% 20 \mathrm{~A} \% 20$ sound $\% 20$ environmental $\% 20$ management $\% 20$ strategy $\% 3 \mathrm{~F} \&$ $\underline{\text { rft. }}$ volume $=44 \&$ rft.issue $=5 \&$ rft. spage $=8 \&$ rft.epage $=21 \&$ rft.date $=2002 \&$ rft.aulast $=$ Bai $\&$ rft.aufirst $=$ X.\%20M.\&rfr $\mathrm{id}=$ info\%3Asid $\% 2$ Fwiley.com\%3AOnlineLibrary)

Bai, X. M. 2003. The process and mechanism of urban environmental change: An evolutionary view. International Journal of Environment and Pollution 19(5): 528-541. CAS (/resolve/reference/CAS?id=1:CAS:528:DC\%2BD3sXnslKgsL0\%3D), Web of

Science ${ }^{\circledR}$ Times Cited: 15 (/resolve/reference/ISI?id $=000185546000011$ ) (?url_ver $=$ Z39.88-2004\&

rft_val_fmt $=$ info $\% 3$ Aofi $\% 2 \mathrm{Ffmt} \% 3 \mathrm{Akev} \% 3 \mathrm{Amtx} \% 3$ Ajournal\&rft.genre $=$ article $\&$ rft.jtitle=International\%20Journal\%20of\%20Environment $\% 20$ and $\% 20$ Pollution\& rft.atitle $=$ The $\% 20$ process $\% 20$ and $\% 20$ mechanism $\% 20$ of $\% 20$ urban $\% 20$ environmental $\% 2$ ( $\% 3 \mathrm{~A} \% 20 \mathrm{An} \% 20$ evolutionary $\% 20$ view $\&$ rft.volume $=19 \&$ rft.issue $=5 \&$ rft.spage $=528 \&$ rft.epage $=541 \&$ rft.date $=2003 \&$ rft.aulast $=$ Bai\&rft.aufirst $=$ X. $\% 20$ M. $\&$

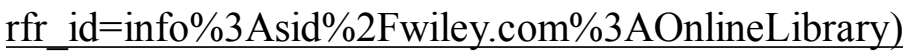

Bai, X. M. 2007. Industrial ecology and the global impact of cities. Journal of Industrial Ecology 11(2): 1-6.

Direct Link:

○ Abstract (/doi/10.1162/jie.2007.1296/abstract)

$\circ \underline{\operatorname{PDF}(59 \mathrm{~K})(/ \mathrm{doi} / 10.1162 / \mathrm{jie} .2007 .1296 / \mathrm{pdf})}$

$\circ \underline{\text { References (/doi/10.1162/jie.2007.1296/references) }}$

(?url ver=Z39.88-2004\&

$\underline{\text { rft val fmt }=\text { info } \% 3 \text { Aofi } \% 2 \mathrm{Ffmt} \% 3 \mathrm{Akev} \% 3 \mathrm{Amtx} \% 3 \mathrm{Ajournal} \& \mathrm{rft} . g e n r e=\text { article } \&}$ rft.jtitle $=$ Journal $\% 20$ of $\% 20$ Industrial $\% 20$ Ecology \& rft.atitle $=$ Industrial $\% 20$ ecology $\% 20$ and $\% 20$ the $\% 20$ global $\% 20$ impact $\% 20$ of $\% 20$ cities \& $\underline{\text { rft.volume }}=11 \&$ rft.issue $=2 \&$ rft.spage $=1 \&$ rft.epage $=6 \&$ rft.date $=2007 \&$ rft. aulast $=$ Bai $\&$ rft.aufirst $=$ X.\%20M.\&rfr id=info\%3Asid $\% 2$ Fwiley.com\%3AOnlineLibrary)

Bai, X. M. and H. Imura. 2000. A comparative study of urban environment in East Asia: Stage model of urban environmental evolution. International Review for Environmental Strategies 1(1): 135-158. (?url_ver=Z39.88-2004\&

$\underline{\text { rft val fmt }=\text { info } \% 3 \text { Aofi } \% 2 \mathrm{Ffmt} \% 3 \mathrm{Akev} \% 3 \mathrm{Amtx} \% 3 \mathrm{Ajournal} \& \mathrm{rft} . \mathrm{genre}=\text { article } \&}$ rft.jtitle=International $\% 20$ Review $\% 20$ for $\% 20$ Environmental $\% 20$ Strategies \& rft.atitle $=\mathrm{A} \% 20$ comparative $\% 20$ study $\% 20$ of $\% 20$ urban $\% 20$ environment $\% 20 \mathrm{in} \% 20$ East $\%$ \%3A\%20Stage $\% 20$ model $\% 20$ of $\% 20$ urban $\% 20$ environmental $\% 20$ evolution\& $\underline{\text { rft. }}$ volume $=1 \&$ rft.issue $=1 \&$ rft.spage $=135 \&$ rft.epage $=158 \&$ rft.date $=2000 \&$ rft.aulast=Bai\&rft.aufirst $=$ X.\%20M.\& 
$\underline{\mathrm{rfr} \text { id }=\mathrm{info} \% 3 \mathrm{Asid} \% 2 \mathrm{Fwiley.com} \% 3 \mathrm{AOnlineLibrary)}}$

Bjorklund, A., C. Bjuggren, M. Dalemo, and U. Sonesson. 1999. Planning biodegradable waste management in Stockholm. Journal of Industry Ecology 3(4): 43-58.

Direct Link:

$\circ \underline{\text { Abstract (/doi/10.1162/108819899569683/abstract) }}$

- $\underline{\operatorname{PDF}(279 \mathrm{~K})(/ \mathrm{doi} / 10.1162 / 108819899569683 / \mathrm{pdf})}$

$\circ$ References (/doi/10.1162/108819899569683/references)

(?url ver $=$ Z39.88-2004\&

rft_val_fmt $=$ info $\% 3$ Aofi $\% 2 \mathrm{Ffmt} \% 3 \mathrm{Akev} \% 3 \mathrm{Amtx} \% 3 \mathrm{Ajournal} \& \mathrm{rft} . \mathrm{genre}=$ article $\&$ rft.jtitle $=$ Journal $\% 20$ of $\% 20$ Industry $\% 20$ Ecology \&

rft.atitle $=$ Planning $\% 20$ biodegradable $\% 20$ waste $\% 20$ management $\% 20$ in $\% 20$ Stockholm $\&$ $\underline{\text { rft. }}$ volume $=3 \&$ rft.issue $=4 \&$ rft.. page $=43 \&$ rft.epage $=58 \&$ rft.date $=1999 \&$

rft.aulast=Bjorklund\&rft.aufirst $=$ A.\&

rfr id=info $\% 3$ Asid $\% 2$ Fwiley.com $\% 3$ AOnlineLibrary)

BMEDI (Beijing General Municipal Engineering Design \& Research Institute). 2006.

Watersupply \& drainage design handbook: Urban drainage, 2nd ed. [in Chinese].

Beijing : China Architecture \& Building Press. (?urlver=Z39.88-2004\&

rft val fmt=info $\% 3$ Aofi $\% 2$ Ffmt $\% 3$ Akev $\% 3$ Amtx $\% 3$ Abook\&rft.genre=book\&

rft.btitle $=$ Watersupply $\% 20 \% 26 \% 20$ drainage $\% 20$ design $\% 20$ handbook

$\% 3 \mathrm{~A} \% 20$ Urban $\% 20$ drainage $\% 2 \mathrm{C} \% 202 \mathrm{nd} \% 20 \mathrm{ed} . \% 20 \% 5 \mathrm{Bin} \% 20 \mathrm{Chinese} \% 5 \mathrm{D} \&$

rft.date $=2006 \&$ rfr $\mathrm{id}=$ info $\% 3$ Asid $\% 2$ Fwiley.com $\% 3$ AOnlineLibrary)

Chen, M., J. Chen, and F. Sun. 2008. Agricultural phosphorus flow and its environmental impacts in China. Science of the Total Environment 405(1-3): 140-152.

CrossRef (/resolve/reference/XREF?id=10.1016/j.scitotenv.2008.06.031), PubMed (/r /reference/PMED?id=18649924), CAS (/resolve/reference

/CAS?id=1:CAS:528:DC\%2BD1cXhtFOjurvL), Web of Science ${ }^{\circledR}$ Times Cited: 18 $\underline{(/ \text { resolve/reference/ISI?id }=000260941300015)}$

(?url ver=Z39.88-2004\&

$\underline{\text { rft val fmt }=\text { info } \% 3 \text { Aofi } \% 2 F f m t \% 3 A k e v \% 3 \text { Amtx } \% 3 \text { Ajournal\&rft.genre }=\text { article } \&}$

rft.jtitle $=$ Science $\% 20$ of $\% 20$ the $\% 20$ Total $\% 20$ Environment $\&$

rft.atitle=Agricultural $\% 20$ phosphorus $\% 20$ flow $\% 20$ and $\% 20 \mathrm{its} \% 20$ environmental $\% 20 \mathrm{imp}$ rft. volume $=405 \&$ rft.issue $=1 \% \mathrm{E} 2 \% 80 \% 933 \&$ rft. .spage $=140 \&$ rft.epage $=152 \&$

rft.date $=2008 \&$ rft.aulast $=$ Chen $\&$ rft.aufirst $=$ M. $\&$

$\underline{\mathrm{rfr} \text { id }=\mathrm{info} \% 3 \mathrm{Asid} \% 2 \mathrm{Fwiley.com} \% 3 \text { AOnlineLibrary) }}$

CMEP (Chinese Ministry of Environmental Protection). 2002. Discharge standard of pollutants for municipal wastewater treatment plants (GB18918-2002). Beijing : Chinese Environmental Science Publishing. http://english.mep.gov.cn /standards_reports/standards/water_environment/Discharge_standard/200710 /t20071024_111808.htm (http://english.mep.gov.cn/standards_reports/standards /water_environment/Discharge_standard/200710/t20071024_111808.htm). Accessed on 
17 May 2011. (?url ver $=$ Z39.88-2004\&

rft val fmt=info $\% 3$ Aofi $\% 2 \mathrm{Ffmt} \% 3 \mathrm{Akev} \% 3 \mathrm{Amtx} \% 3 \mathrm{Abook} \& \mathrm{rft} . \mathrm{genre}=$ book\& rft.btitle=Discharge $\% 20$ standard $\% 20$ of $\% 20$ pollutants $\% 20$ for $\% 20$ municipal $\% 20$ wastewat $\% 20 \% 28 \mathrm{~GB} 18918 \% \mathrm{E} 2 \% 80 \% 902002 \% 29 \&$ rft.date $=2002 \&$ $\underline{\mathrm{rfr} \text { id }=\text { info } \% 3 \text { Asid } \% 2 \text { Fwiley.com } \% 3 \text { AOnlineLibrary) }}$

CMEP (Chinese Ministry of Environmental Protection). Various years (1995-2008). Statistic communique on environment in China. Beijing : Chinese Ministry of Environmental Protection. (?url ver $=\mathrm{Z} 39.88-2004 \&$ rft val $\mathrm{fmt}=$ info $\% 3$ Aofi $\% 2 \mathrm{Ffmt} \% 3 \mathrm{Akev} \% 3 \mathrm{Amtx} \% 3$ Abook\&rft.genre=book\& rft.btitle $=$ Statistic $\% 20$ communique $\% 20$ on $\% 20$ environment $\% 20 \mathrm{in} \% 20$ China\& rfr $\mathrm{id}=\mathrm{info} \% 3$ Asid $\% 2$ Fwiley.com $\% 3$ AOnlineLibrary)

Cordell, D., J. O. Drangert, and S. White. 2009. The story of phosphorus: Global food security and food for thought. Global Environmental Change 19(2): 292-305.

CrossRef (/resolve/reference/XREF?id=10.1016/j.gloenvcha.2008.10.009), Web of Science ${ }^{\circledR}$ Times Cited: 136 (/resolve/reference/ISI?id=000266539000016) (?url_ver $=$ Z39.88-2004\& $\underline{\text { rft val fmt }=\text { info } \% 3 \text { Aofi } \% 2 \mathrm{Ffmt} \% 3 \mathrm{Akev} \% 3 \mathrm{Amtx} \% 3 \mathrm{Ajournal} \& \mathrm{rft} . \mathrm{genre}=\text { article } \&}$ rft.jtitle $=$ Global $\% 20$ Environmental $\% 20$ Change \& rft.atitle $=$ The $\% 20$ story $\% 20$ of $\% 20$ phosphorus $\% 3 \mathrm{~A} \% 20$ Global $\% 20$ food $\% 20$ security $\% 20$ and $\% 20$ food $\% 20$ for $\% 20$ thought \&

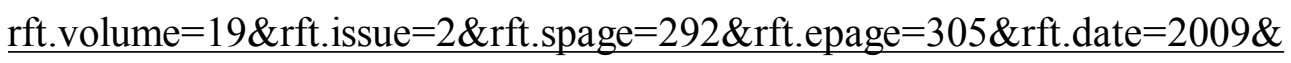
$\underline{\text { rft.aulast }=\text { Cordell\&rft.aufirst }=\text { D.\&rfr } \mathrm{id}=\text { info } \% 3 \text { Asid } \% 2 \text { Fwiley.com } \% 3 \text { AOnlineLibrary) }}$

Decker, E. H., S. Elliott, F. A. Smith, D. R. Blake, and F. S. Rowland. 2000. Energy and material flow through the urban ecosystem. Annual Review of Energy and the Environment 25: 685-740.

CrossRef (/resolve/reference/XREF?id=10.1146/annurev.energy.25.1.685), Web of

Science ${ }^{\circledR}$ Times Cited: 64 (/resolve/reference/ISI?id=000166624500020) (?url ver $=$ Z39.88-2004\& rft_val_fmt=info $\% 3$ Aofi $\% 2 F f m t \% 3 A k e v \% 3$ Amtx $\% 3$ Ajournal\&rft.genre $=$ article $\&$ rft.jtitle $=$ Annual $\% 20$ Review\%20of\%20Energy $\% 20$ and $\% 20$ the $\% 20$ Environment\& rft.atitle $=$ Energy $\% 20$ and $\% 20$ material $\% 20$ flow $\% 20$ through $\% 20$ the $\% 20$ urban $\% 20$ ecosyst $\underline{\text { rft. }}$ volume $=25 \&$ rft. .spage $=685 \&$ rft.epage $=740 \&$ rft. date $=2000 \&$ rft.aulast $=$ Decker $\&$ rft.aufirst=E.\%20H.\&rfr id=info\%3Asid\%2Fwiley.com\%3AOnlineLibrary)

Farge, J., J. Magid, and F. W. T. Penning de Vries. 2001. Urban nutrient balance for Bangkok. Ecological Modelling 139: 63-74.

CrossRef (/resolve/reference/XREF?id=10.1016/S0304-3800(01)00233-2) (?url ver $=$ Z39.88-2004\& $\underline{\mathrm{rft} \text { val } \mathrm{fmt}=\text { info } \% 3 \mathrm{Aofi} \% 2 \mathrm{Ffmt} \% 3 \mathrm{Akev} \% 3 \mathrm{Amtx} \% 3 \mathrm{Ajournal} \& \mathrm{rft} . \text { genre }=\text { article } \&}$ rft.jtitle=Ecological $\% 20$ Modelling\& rft.atitle $=$ Urban $\% 20$ nutrient $\% 20$ balance $\% 20$ for $\% 20$ Bangkok $\&$ rft. volume $=139 \&$ $\underline{\text { rft.spage }=63 \& \text { rft.epage }=74 \& \text { rft.date }=2001 \& \text { rft.aulast }=\text { Farge } \& \text { rft.aufirst }=\text { J. } \&}$ 
rfr id=info $\% 3$ Asid $\% 2$ Fwiley.com $\% 3$ AOnlineLibrary)

Feng, Z. and D. Shi. 2006. Chinese food consumption and nourishment in the latest 20 years. Resources Science 28(1): 2-8 [in Chinese, with English abstract.

(?url_ver=Z39.88-2004\&

$\underline{\text { rft_val fmt }=\text { info } \% 3 \mathrm{Aofi} \% 2 \mathrm{Ffmt} \% 3 \mathrm{Akev} \% 3 \mathrm{Amtx} \% 3 \mathrm{Ajournal} \& \mathrm{rft} . \mathrm{genre}=\text { article } \&}$ rft.jtitle $=$ Resources $\% 20$ Science $\&$

rft.atitle $=$ Chinese $\% 20$ food $\% 20$ consumption $\% 20$ and $\% 20$ nourishment $\% 20 \mathrm{in} \% 20$ the $\% 20 \mathrm{l}$ $\underline{\text { rft.volume }}=28 \& \mathrm{rft}$.issue $=1 \& \mathrm{rft}$. spage $=2 \& \mathrm{rft}$.epage $=8 \& \mathrm{rft}$.date $=2006 \& \mathrm{rft}$.aulast $=$ Feng $\&$

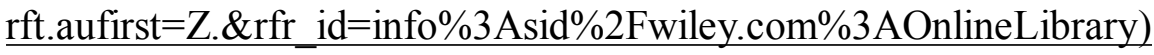

Forkes, J. 2007. Nitrogen balance for the urban food metabolism of Toronto, Canada. Resources, Conservation and Recycling 52(1): 74-94.

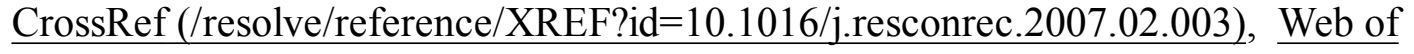

Science ${ }^{\circledR}$ Times Cited: 11 (/resolve/reference/ISI?id=000250236500006)

(?url ver $=$ Z39.88-2004\&

rft val fmt $=$ info $\% 3$ Aofi $\% 2 F f m t \% 3$ Akev $\% 3$ Amtx $\% 3$ Ajournal\&rft.genre $=$ article $\&$ rft.jtitle $=$ Resources $\% 2 \mathrm{C} \% 20$ Conservation $\% 20$ and $\% 20$ Recycling\&

rft.atitle $=$ Nitrogen $\% 20$ balance $\% 20$ for $\% 20$ the $\% 20$ urban $\% 20$ food $\% 20$ metabolism $\% 20 \mathrm{of} \%$, $\% 2 \mathrm{C} \% 20$ Canada\&rft.volume $=52 \&$ rft.issue $=1 \&$ rft.spage $=74 \&$ rft.epage $=94 \&$ rft.date $=2007 \&$ rft.aulast $=$ Forkes $\&$ rft.aufirst $=$ J.\& $\underline{\mathrm{rfr} \text { id=info } \% 3 \text { Asid } \% 2 \text { Fwiley.com } \% 3 \text { AOnlineLibrary) }}$

Grimm, N. B., S. H. Faeth, N. E. Golubiewski, C. L. Redman, J. Wu, X. Bai, and J. M. Briggs. 2008. Global change and the ecology of cities. Science 319: 756-760.

CrossRef (/resolve/reference/XREF?id=10.1126/science.1150195), PubMed (/resolve /reference/PMED?id=18258902), $\underline{\text { CAS (/resolve/reference }}$

/CAS?id=1:CAS:528:DC\%2BD1cXhsFGhsLw\%3D), Web of Science ${ }^{\circledR}$ Times Cite 190 (/resolve/reference/ISI?id=000252963000045), $\underline{\text { ADS (/resolve/reference }}$ /ADS?id=2008Sci...319..756G)

(?url ver $=$ Z39.88-2004\&

rft_val_fmt $=$ info $\% 3$ Aofi $\% 2 F f m t ~ \% 3 A k e v \% 3 A m t x \% 3$ Ajournal\&rft.genre $=$ article $\&$ $\underline{\text { rft.jtitle }=\text { Science } \&}$

rft.atitle $=$ Global $\% 20$ change $\% 20$ and $\% 20$ the $\% 20$ ecology $\% 20$ of $\% 20$ cities \&

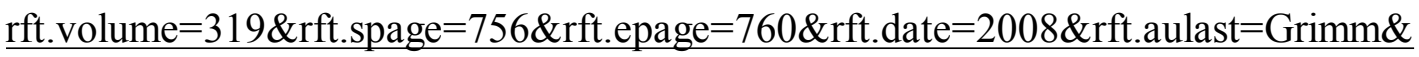
rft.aufirst $=$ N.\%20B.\&rfr id $=$ info $\% 3$ Asid $\% 2$ Fwiley.com $\% 3$ AOnlineLibrary)

INFS, China CDC (Institute of Nutrition and Food Safety, Chinese Centre for Disease Control and Prevention). 2005. China food composition 2004 (Book 2). Beijing : Peking University Medical Press [in Chinese]. (?url ver $=\mathrm{Z39} 988-2004 \&$ rft_val fmt $=$ info $\% 3$ Aofi $\% 2 F f m t \% 3 A k e v \% 3$ Amtx $\% 3$ Abook\&rft.genre=book\& rft.btitle=China $\% 20$ food $\% 20$ composition $\% 202004 \% 20 \% 28$ Book $\% 202 \% 29 \&$ rft.date $=2005 \& \mathrm{rfr} \_\mathrm{id}=$ info $\% 3$ Asid $\% 2$ Fwiley.com $\% 3$ AOnlineLibrary)

Kaye, J. P., P. M. Groffman, N. B. Grimm, L. A. Baker, and R. V. Pouyat. 2006. A distinct urban biogeochemistry? Trends in Ecology and Evolution 21(4): 192-199. 
CrossRef (/resolve/reference/XREF?id=10.1016/j.tree.2005.12.006), PubMed (/resolv /reference/PMED?id=16701085), Web of Science ${ }^{\circledR}$ Times Cited: 69 (/resolve/refe ISI?id=000237144500007)

(?url ver $=$ Z39.88-2004\&

rft val $\mathrm{fmt}=\mathrm{info} \% 3 \mathrm{Aofi} \% 2 \mathrm{Ffmt} \% 3 \mathrm{Akev} \% 3 \mathrm{Amtx} \% 3 \mathrm{Ajournal} \& \mathrm{rft} . \mathrm{genre}=$ article $\&$ rft.jtitle $=$ Trends $\% 20$ in $\% 20$ Ecology $\% 20$ and $\% 20$ Evolution\& rft.atitle $=\mathrm{A} \% 20$ distinct $\% 20$ urban $\% 20$ biogeochemistry $\% 3 \mathrm{~F} \& \mathrm{rft}$. volume $=21 \&$ rft.issue $=4 \&$ rft.spage $=192 \&$ rft.epage $=199 \&$ rft.date $=2006 \&$ rft.aulast $=$ Kaye $\&$ $\underline{\text { rft.aufirst }=\text { J.\%20P.\&rfr id=info\%3Asid } \% 2 \text { Fwiley.com\%3AOnlineLibrary) }}$

Kennedy, C., J. Cuddihy, and J. Engel-Yan. 2007. The changing metabolism of cities. Journal of Industrial Ecology 11(2): 43-59.

Direct Link:

$\circ$ Abstract (/doi/10.1162/jie.2007.1107/abstract)

$\circ \underline{\operatorname{PDF}(2120 \mathrm{~K})(/ \mathrm{doi} / 10.1162 / \mathrm{jie} .2007 .1107 / \mathrm{pdf})}$

$\circ$ References (/doi/10.1162/jie.2007.1107/references)

(?url ver $=$ Z39.88-2004\&

rft_val_fmt $=$ info $\% 3$ Aofi $\% 2 F f m t \% 3 A k e v \% 3 A m t x \% 3$ Ajournal\&rft.genre $=$ article $\&$ rft.jtitle $=$ Journal $\% 20 \mathrm{of} \% 20$ Industrial $\% 20$ Ecology \& rft.atitle $=$ The $\% 20$ changing $\% 20$ metabolism $\% 20$ of $\% 20$ cities \&rft.volume $=11 \&$ $\underline{\text { rft.issue }}=2 \&$ rft.spage $=43 \&$ rft.epage $=59 \&$ rft.date $=2007 \&$ rft.aulast $=$ Kennedy $\&$ rft.aufirst $=$ C.\&rfr $\_$id $=$info $\% 3$ Asid $\% 2$ Fwiley.com $\% 3$ AOnlineLibrary)

Klee, R. J., and T. E. Graedel. 2004. Elemental cycles: A status report on human or natural dominance. Annual Review of Environment and Resources 29:69-107.

CrossRef (/resolve/reference/XREF?id=10.1146/annurev.energy.29.042203.104034), I of Science ${ }^{\circledR}$ Times Cited: 26 (/resolve/reference/ISI?id=000225744400004) (?url ver $=$ Z39.88-2004\& rft val fmt $=$ info $\% 3$ Aofi $\% 2 F f m t \% 3$ Akev $\% 3$ Amtx $\% 3$ Ajournal\&rft.genre=article $\&$ rft.jtitle=Annual $\% 20$ Review $\% 20$ of $\% 20$ Environment $\% 20$ and $\% 20$ Resources \& rft.atitle $=$ Elemental $\% 20$ cycles \%3A\%20A\%20status\%20report $\% 20$ on $\% 20$ human $\% 20$ or $\% 20$ natural\%20dominance \&

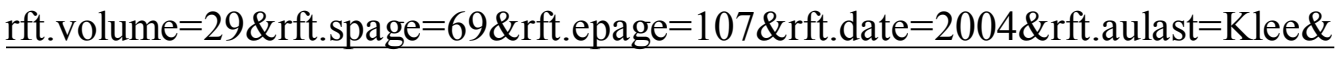
rft.aufirst=R.\%20J.\&rfr id=info $\% 3$ Asid $\% 2$ Fwiley.com\%3AOnlineLibrary)

Li, G. L., J. Chen, and Z. Sun. 2007. Non-agricultural land expansion and its driving forces: A multi-temporal study of Suzhou, China. International Journal of Sustainable Development and World Ecology 14(4): 408-420.

CrossRef (/resolve/reference/XREF?id=10.1080/13504500709469741), Web of Scienc Times Cited: 2 (/resolve/reference/ISI?id=000248793100009) (?url_ver=Z39.88-2004\& $\underline{\text { rft val fmt }=\text { info } \% 3 \text { Aofi } \% 2 \mathrm{Ffmt} \% 3 \mathrm{Akev} \% 3 \mathrm{Amtx} \% 3 \mathrm{Ajournal} \& \mathrm{rft} . \mathrm{genre}=\text { article } \&}$ rft.jtitle=International $\% 20$ Journal $\% 20$ of $\% 20$ Sustainable $\% 20$ Development $\% 20$ and $\% 20 \mathrm{~W}$ 
rft.atitle $=$ Non $\% \mathrm{E} 2 \% 80$

\%90agricultural $\% 20$ land $\% 20$ expansion $\% 20$ and $\% 20$ its $\% 20$ driving\%20forces

\%3A\%20A\%20multi\%E2\%80\%90temporal $\% 20$ study $\% 20$ of $\% 20$ Suzhou

$\% 2 \mathrm{C} \% 20 \mathrm{China} \& \mathrm{rft}$. volume $=14 \& \mathrm{rft}$.issue $=4 \& \mathrm{rft}$. spage $=408 \&$ rft.epage $=420 \&$

$\underline{\text { rft.date }=2007 \& \text { rft.aulast }=\text { Li\&rft.aufirst }=\text { G. } \% 20 \text { L.\& }}$

rfr id=info $\% 3$ Asid $\% 2$ Fwiley.com $\% 3$ AOnlineLibrary)

Liu, J., J. Zhan, and X. Deng. 2005. Spatio-temporal patterns and driving forces of urban land expansion in China during the economic reform era. AMBIO 34(6): 450-455.

$\underline{\text { PubMed (/resolve/reference/PMED?id=16201216), Web of Science }{ }^{\circledR} \text { Times Cited: } 34}$ (/resolve/reference/ISI?id=000231178800006)

(?url ver $=$ Z39.88-2004\&

rft_val_fmt $=$ info $\% 3$ Aofi $\% 2 F f m t \% 3 A k e v \% 3 A m t x \% 3$ Ajournal\&rft.genre $=$ article $\&$ rft.jtitle $=$ AMBIO\&rft.atitle $=$ Spatio $\% \mathrm{E} 2 \% 80$

\%90temporal $\% 20$ patterns $\% 20$ and $\% 20$ driving $\% 20$ forces $\% 20$ of $\% 20$ urban $\% 201$ land $\% 20$ ex rft.volume $=34 \&$ rft.issue $=6 \&$ rft. spage $=450 \&$ rft.epage $=455 \&$ rft.date $=2005 \&$ rft.aulast $=$ Liu\&rft.aufirst $=$ J.\&rfr $\mathrm{id}=$ info $\% 3$ Asid $\% 2$ Fwiley.com $\% 3$ AOnlineLibrary)

Liu, Y. and J. Chen. 2006. Substance flow analysis of phosphorus cycle system in China. China Environmental Science 26(2): 238-242 [in Chinese, with English abstract. (?url ver $=$ Z39.88-2004\&

rft val fmt $=$ info $\% 3$ Aofi $\% 2 F f m t \% 3$ Akev $\% 3$ Amtx $\% 3$ Ajournal\&rft.genre $=$ article $\&$ rft.jtitle $=$ China $\% 20$ Environmental $\% 20$ Science $\&$

rft.atitle $=$ Substance $\% 20$ flow $\% 20$ analysis $\% 20$ of $\% 20$ phosphorus $\% 20$ cycle $\% 20$ system $\% 2 C$ rft.volume $=26 \&$ rft.issue $=2 \&$ rft. .spage $=238 \&$ rft.epage $=242 \&$ rft.date $=2006 \&$ rft.aulast=Liu\&rft.aufirst=Y.\&rfr id=info\%3Asid\%2Fwiley.com\%3AOnlineLibrary)

Liu, Y., J. Chen, A. P. J. Mol, and R. U. Ayres. 2007. Comparative analysis of phosphorus use within national and local economies in China. Resources, Conservation and Recycling 51(2): 454-474.

CrossRef (/resolve/reference/XREF?id=10.1016/j.resconrec.2006.10.012), Web of

$\underline{\text { Science }}{ }^{\circledR}$ Times Cited: 4 (/resolve/reference/ISI?id=000247291100012) (?url ver=Z39.88-2004\& rft_val_fmt $=$ info $\% 3$ Aofi $\% 2 F f m t \% 3 A k e v \% 3$ Amtx $\% 3$ Ajournal\&rft.genre $=$ article $\&$ rft.jtitle= $=$ Resources $\% 2 \mathrm{C} \% 20$ Conservation $\% 20$ and $\% 20$ Recycling\& rft.atitle $=$ Comparative $\% 20$ analysis $\% 20$ of $\% 20$ phosphorus $\% 20$ use $\% 20$ within $\% 20$ national ${ }^{\prime}$ rft.. olume $=51 \&$ rft.issue $=2 \&$ rft.spage $=454 \&$ rft.epage $=474 \&$ rft.date $=2007 \&$ rft.aulast $=$ Liu\&rft.aufirst $=$ Y.\&rfr_id $=$ info $\% 3$ Asid $\% 2$ Fwiley.com $\% 3$ AOnlineLibrary)

Liu, Y., G. Villalba, R. U. Ayres, and H. Schroder. 2008. Global phosphorus flows and environmental impacts from a consumption perspective. Journal of Industrial Ecology 12(2): 229-247.

Direct Link:

○ Abstract (/doi/10.1111/j.1530-9290.2008.00025.x/abstract)

$\circ$ Full Article (HTML) (/doi/10.1111/j.1530-9290.2008.00025.x/full) 
○ $\underline{\operatorname{PDF}(3143 \mathrm{~K})(/ \mathrm{doi} / 10.1111 / \mathrm{j} .1530-9290.2008 .00025 . \mathrm{x} / \mathrm{pdf})}$

○ References (/doi/10.1111/j.1530-9290.2008.00025.x/references)

(?url ver $=\mathrm{Z} 39.88-2004 \&$

$\underline{\text { rft val fmt }=\text { info } \% 3 \text { Aofi } \% 2 \mathrm{Ffmt} \% 3 \mathrm{Akev} \% 3 \mathrm{Amtx} \% 3 \mathrm{Ajournal} \& \mathrm{rft} . \mathrm{genre}=\text { article } \&}$ rft.jtitle $=$ Journal $\% 20 \mathrm{of} \% 20$ Industrial $\% 20$ Ecology \&

rft.atitle $=$ Global $\% 20$ phosphorus $\% 20$ flows $\% 20$ and $\% 20$ environmental $\% 20$ impacts $\% 20$ fro

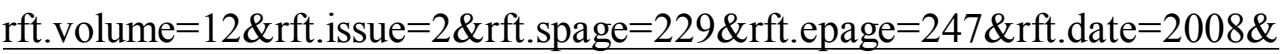
rft.aulast $=$ Liu\&rft.aufirst $=$ Y.\&rfr $\mathrm{id}=$ info $\% 3 \mathrm{Asid} \% 2 \mathrm{Fwiley}$. com $\% 3 \mathrm{AOnlineLibrary)}$

Lv, Y. H. 1994. Urban human excreta and solid waste in Hebei Province and its countermeasure. Hebei Agricultural Science 5: 24-25. (?url_ver=Z39.88-2004\& rft_val_fmt $=$ info $\% 3$ Aofi $\% 2 F f m t ~ \% 3 A k e v \% 3 \mathrm{Amtx} \% 3$ Ajournal\&rft.genre $=$ article $\&$ rft.jtitle=Hebei\%20Agricultural $\% 20$ Science \&

rft.atitle $=$ Urban $\% 20$ human $\% 20$ excreta $\% 20$ and $\% 20$ solid $\% 20$ waste $\% 20 \mathrm{in} \% 20$ Hebei $\% 20 \mathrm{~F}$ $\underline{\text { rft. }}$ volume $=5 \&$ rft. .spage $=24 \&$ rft.epage $=25 \&$ rft.date $=1994 \&$ rft.aulast $=$ Lv $\&$ rft.aufirst=Y.\%20H.\&rfr_id=info\%3Asid\%2Fwiley.com\%3AOnlineLibrary)

Ma, G. S., C. H. Cui, X. Q. Hu, Y. P. Li, Y. N. He, F. Y. Zhai, and X. G. Yang. 2006. The food consumption and outside eating behavior of Chinese residents. Food and Nutrition in China 12: 4-8 [in Chinese, with English abstract. (?url ver=Z39.88-2004\& rft val $\mathrm{fmt}=\mathrm{info} \% 3 \mathrm{Aofi} \% 2 \mathrm{Ffmt} \% 3 \mathrm{Akev} \% 3 \mathrm{Amtx} \% 3 \mathrm{Ajournal} \& \mathrm{rft} . \mathrm{genre}=$ article $\&$ rft.jtitle $=$ Food $\% 20$ and $\% 20$ Nutrition $\% 20$ in $\% 20$ China\& rft.atitle $=$ The $\% 20$ food $\% 20$ consumption $\% 20$ and $\% 20$ outside $\% 20$ eating $\% 20$ behavior $\% 20 \mathrm{c}$

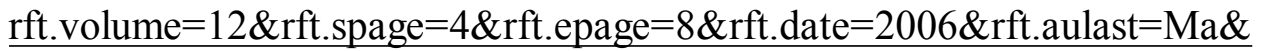
rft.aufirst $=$ G. $\% 20$ S.\&rfr id $=$ info $\% 3$ Asid $\% 2$ Fwiley.com $\% 3$ AOnlineLibrary)

Mnkeni, P. N. S. and L. M. Austin. 2009. Fertilizer value of human manure from pilot urinediversion toilets. Water SA 35(1): 133-138.

CAS (/resolve/reference/CAS?id=1:CAS:528:DC\%2BD1MXjs12rurw\%3D), Web of

Science ${ }^{\circledR}$ Times Cited: 2 (/resolve/reference/ISI?id=000265559400018) (?url_ver=Z39.88-2004\& $\underline{\text { rft_val_fmt }=\text { info } \% 3 \text { Aofi } \% 2 \mathrm{Ffmt} \% 3 \mathrm{Akev} \% 3 \mathrm{Amtx} \% 3 \mathrm{Ajournal} \& \mathrm{rft} . \mathrm{genre}=\text { article } \&}$ rft.jtitle $=$ Water $\% 20$ SA\& rft.atitle=Fertilizer $\% 20$ value $\% 20$ of $\% 20$ human $\% 20$ manure $\% 20$ from $\% 20$ pilot $\% 20$ urine $\% \mathrm{E} 2 \% 80 \% 90$ diversion $\% 20$ toilets $\&$ rft.volume $=35 \& \mathrm{rft}$.issue $=1 \& \mathrm{rft}$. spage $=133 \&$ $\underline{\text { rft.epage }=138 \& \text { rft.date }=2009 \& \text { rft.aulast }=\text { Mnkeni\&rft.aufirst }=\text { P. } \% 20 \text { N. } \% 20 \text { S. } \&}$ rfr_id=info $\% 3$ Asid $\% 2$ Fwiley.com $\% 3$ AOnlineLibrary)

MOC (Ministry of Construction). 2007. China urban construction statistical yearbook 2006. Beijing : China Architecture \& Building Press. (?url_ver=Z39.88-2004\& rft val fmt=info $\% 3$ Aofi $\% 2 \mathrm{Ffmt} \% 3 \mathrm{Akev} \% 3 \mathrm{Amtx} \% 3$ Abook\&rft.genre=book\& rft.btitle $=$ China $\% 20$ urban $\% 20$ construction $\% 20$ statistical $\% 20$ yearbook $\% 202006 \&$ $\underline{\text { rft.date }=2007 \& \text { rfr id }=\text { info } \% 3 \text { Asid } \% 2 \text { Fwiley.com } \% 3 \text { AOnlineLibrary) }}$

Mohanty, S., N. K. Paikaray, and A. R. Rajan. 2006. Availability and uptake of phosphorus 
from organic manures in groundnut (Arachis hypogeal L.)-corn (Zea mays L.) sequence using radio tracer technique. Geoderma 133: 225-230.

CrossRef (/resolve/reference/XREF?id=10.1016/j.geoderma.2005.07.009), CAS (/reso /reference/CAS?id=1:CAS:528:DC\%2BD28XmtlOnsbY\%3D), Web of Science $\left.{ }^{\circledR}\right]$

Cited: 6 (/resolve/reference/ISI?id=000238981300007)

(?url_ver=Z39.88-2004\&

$\underline{\text { rft_val_fmt }=\text { info } \% 3 \text { Aofi } \% 2 \mathrm{Ffmt} \% 3 \mathrm{Akev} \% 3 \mathrm{Amtx} \% 3 \mathrm{Ajournal} \& \mathrm{rft} . \mathrm{genre}=\text { article } \&}$ rft.jtitle $=$ Geoderma\&

rft.atitle $=$ Availability $\% 20$ and $\% 20$ uptake $\% 20$ of $\% 20$ phosphorus $\% 20$ from $\% 20$ organic $\% 20$ $\% 20 \% 28$ Arachis $\% 20$ hypogeal\%20L.\%29\%E2\%80\%90corn

$\% 20 \% 28$ Zea $\% 20$ mays $\% 20 \mathrm{~L}$.

$\% 29 \% 20$ sequence $\% 20$ using $\% 20$ radio $\% 20$ tracer $\% 20$ technique $\&$ rft.volume $=133 \&$

$\underline{\text { rft.spage }=225 \& \text { rft.epage }=230 \& \text { rft.date }=2006 \& \text { rft.aulast }=\text { Mohanty } \& \text { rft.aufirst }=\text { S. } \&}$ rf__id=info $\% 3$ Asid $\% 2$ Fwiley.com $\% 3$ AOnlineLibrary)

National Research Council. 1989. Recommended daily allowances. Washington, DC :

National Research Council, p. 302. http://www.nap.edu

/catalog.php?record_id=1349\#toc (http://www.nap.edu

/catalog.php?record_id=1349\#toc). Accessed 17 May 2011). (?url_ver=Z39.88-2004\&

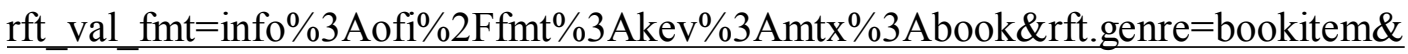
rft.btitle $=$ Recommended $\% 20$ daily $\% 20$ allowances $\&$ rft.spage $=302 \&$ rft.date $=1989 \&$ $\underline{\mathrm{rfr} \mathrm{id}=\mathrm{info} \% 3 \mathrm{Asid} \% 2 \mathrm{Fwiley.com} \% 3 \mathrm{AOnlineLibrary)}}$

NBSC (National Bureau of Statistics of China). Various years (1985-2008). China statistical yearbook. Beijing : China Statistical Press. (?url ver=Z39.88-2004\& $\underline{\mathrm{rft} \text { val_fmt }=\text { info } \% 3 \mathrm{Aofi} \% 2 \mathrm{Ffmt} \% 3 \mathrm{Akev} \% 3 \mathrm{Amtx} \% 3 \mathrm{Abook} \& \mathrm{rft} . \mathrm{genre}=\text { book\& }}$ rft.btitle $=$ China $\% 20$ statistical $\% 20$ yearbook\&

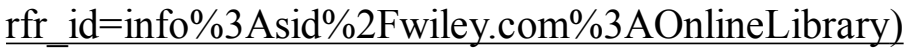

Neset, T. S. S., H. P. Bader, R. Scheidegger, and U. Lohm. 2008. The flow of phosphorus in food production and consumption-Linkoping, Sweden, 1870-2000. Science of the Total Environment 396: 111-120.

CrossRef (/resolve/reference/XREF?id=10.1016/j.scitotenv.2008.02.010), PubMed (/r /reference/PMED?id=18377956), CAS (/resolve/reference /CAS?id=1:CAS:528:DC\%2BD1cXls12rtLs\%3D), Web of Science® Times Cited: (/resolve/reference/ISI?id $=000256748900003)$

(?url ver $=$ Z39.88-2004\& rft_val_fmt $=$ info $\% 3$ Aofi $\% 2 \mathrm{Ffmt} \% 3 \mathrm{Akev} \% 3 \mathrm{Amtx} \% 3$ Ajournal\&rft.genre $=$ article $\&$ rft.jtitle $=$ Science $\% 20$ of $\% 20$ the $\% 20$ Total $\% 20$ Environment $\&$ rft.atitle $=$ The $\% 20$ flow $\% 20$ of $\% 20$ phosphorus $\% 20 \mathrm{in} \% 20$ food $\% 20$ production $\% 20$ and $\% 20$, \%E2\%80\%94Linkoping\%2C\%20Sweden $\% 2 \mathrm{C} \% 201870 \% \mathrm{E} 2 \% 80 \% 932000 \&$ $\underline{\text { rft.volume }}=396 \&$ rft. .spage $=111 \&$ rft.epage $=120 \&$ rft.date $=2008 \&$ rft .aulast $=$ Neset $\&$ rft.aufirst $=$ T.\%20S.\%20S.\&rfr id=info\%3Asid $\% 2$ Fwiley.com $\% 3$ AOnlineLibrary)

Newcombe, K. 1977. Nutrient flow in a major urban settlement: Hong Kong. Human 
Ecology 5(3): 179-208.

CrossRef (/resolve/reference/XREF?id=10.1007/BF00891277), Web of Science ${ }^{\circledR}$ Tim

Cited: 16 (/resolve/reference/ISI?id=A1977DX24200001)

(?url_ver=Z39.88-2004\&

$\underline{\text { rft_val_fmt }=\text { info } \% 3 \text { Aofi } \% 2 F f m t ~} \% 3 \mathrm{Akev} \% 3 \mathrm{Amtx} \% 3 \mathrm{Ajournal} \& \mathrm{rft} . g e n r e=$ article $\&$

rft.jtitle $=$ Human $\% 20$ Ecology \&

rft.atitle $=$ Nutrient $\% 20$ flow $\% 20 \mathrm{in} \% 20 \mathrm{a} \% 20$ major $\% 20$ urban $\% 20$ settlement

$\% 3 \mathrm{~A} \% 20$ Hong $\% 20$ Kong\&rft.volume $=5 \&$ rft.issue $=3 \&$ rft.spage $=179 \&$ rft.epage $=208 \&$

$\underline{\text { rft.date }}=1977 \&$ rft.aulast $=$ Newcombe $\&$ rft. aufirst $=$ K. $\&$

rfr_id=info $\% 3$ Asid $\% 2$ Fwiley.com $\% 3$ AOnlineLibrary)

Nilson, J. 1995. A phosphorus budget for a Swedish municipality. Journal of Environmental Management 45(3): 243-253.

CrossRef (/resolve/reference/XREF?id=10.1006/jema.1995.0072), Web of Science ${ }^{\circledR} 1$

Cited: 10 (/resolve/reference/ISI?id=A1995TE75900004)

(?url ver=Z39.88-2004\&

rft val fmt $=$ info $\% 3$ Aofi $\% 2 \mathrm{Ffmt} \% 3 \mathrm{Akev} \% 3 \mathrm{Amtx} \% 3 \mathrm{Ajournal} \& \mathrm{rft} . \mathrm{genre}=$ article $\&$ rft.jtitle $=$ Journal $\% 20 \mathrm{of} \% 20$ Environmental $\% 20$ Management\&

rft.atitle $=\mathrm{A} \% 20$ phosphorus $\% 20$ budget $\% 20$ for $\% 20 \mathrm{a} \% 20$ Swedish $\% 20$ municipality \&

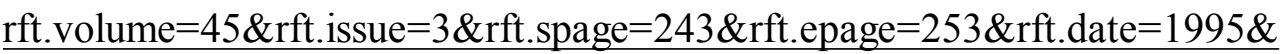
$\underline{\text { rft.aulast }=\text { Nilson } \& \text { rft.aufirst }=\mathrm{J} . \& \mathrm{rfr} \mathrm{id}=\mathrm{info} \% 3 \text { Asid } \% 2 \text { Fwiley.com } \% 3 \text { AOnlineLibrary) }}$

Pickett, S. T. A., M. L. Cadenasso, J. M. Grove, C. H. Nilon, R. V. Pouyat, W. C. Zipperer, and R. Costanza. 2001. Urban ecological systems: Linking terrestrial ecological, physical, and socioeconomic components of metropolitan areas. Annual Review of Ecology and Systematics 32:127-157.

CrossRef (/resolve/reference/XREF?id=10.1146/annurev.ecolsys.32.081501.114012), of Science ${ }^{\circledR}$ Times Cited: 267 (/resolve/reference/ISI?id=000172908800005) (?url_ver=Z39.88-2004\& $\underline{\text { rft_val_fmt }=\text { info } \% 3 \text { Aofi } \% 2 \mathrm{Ffmt} \% 3 \mathrm{Akev} \% 3 \mathrm{Amtx} \% 3 \mathrm{Ajournal} \& \mathrm{rft} . g e n r e=\text { article } \&}$ rft.jtitle=Annual $\% 20$ Review $\% 20 \mathrm{of} \% 20$ Ecology $\% 20$ and $\% 20$ Systematics \& rft.atitle $=$ Urban $\% 20$ ecological $\% 20$ systems $\% 3 \mathrm{~A} \% 20$ Linking\%20terrestrial\%20ecological $\% 2 \mathrm{C} \% 20$ physical $\% 2 \mathrm{C} \% 20$ and $\% 20$ socioeconomic $\% 20$ components $\% 20$ of $\% 20$ metropolitan $\% 20$ areas \&

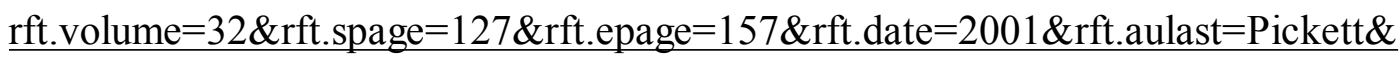
rft.aufirst=S.\%20T.\%20A.\&rfr id=info $\% 3$ Asid $\% 2$ Fwiley.com $\% 3$ AOnlineLibrary)

Satterthwaite, D. 2003. The links between poverty and the environment in urban areas of Africa, Asia, and Latin America. Annals of the American Academy of Political and Social Science 590(1): 73-92.

CrossRef (/resolve/reference/XREF?id=10.1177/0002716203257095), Web of Science Times Cited: 9 (/resolve/reference/ISI?id $=000185881400004)$

(?url ver $=$ Z39.88-2004\&

$\underline{\text { rft val fmt }=\text { info } \% 3 \text { Aofi } \% 2 \mathrm{Ffmt} \% 3 \mathrm{Akev} \% 3 \mathrm{Amtx} \% 3 \mathrm{Ajournal} \& \mathrm{rft} . \mathrm{genre}=\text { article } \&}$ 
rft.jtitle $=$ Annals $\% 20$ of $\% 20$ the $\% 20$ American $\% 20$ Academy $\% 20$ of $\% 20$ Political $\% 20$ and $\%$ rft.atitle $=$ The $\% 20$ links $\% 20$ between $\% 20$ poverty $\% 20$ and $\% 20$ the $\% 20$ environment $\% 20 \mathrm{in} \%$ $\% 2 \mathrm{C} \% 20$ Asia $\% 2 \mathrm{C} \% 20$ and $\% 20$ Latin $\% 20$ America\&rft.volume $=590 \&$ rft.issue $=1 \&$ rft. .spage $=73 \&$ rft.epage $=92 \&$ rft.date $=2003 \&$ rft.aulast $=$ Satterthwaite $\&$ rft .aufirst $=$ D. $\&$ $\underline{\mathrm{rfr} \text { id }=\mathrm{info} \% 3 \mathrm{Asid} \% 2 \text { Fwiley.com } \% 3 \text { AOnlineLibrary) }}$

UN-DESA (United Nations, Department of Economic and Social Affairs, Population Division). 2008. World urbanization prospects: The 2007 revision. New York : United Nations.

Web of Science ${ }^{\circledR}$ Times Cited: 4 (/resolve/reference/ISI?id=000252048700002) (?url ver $=$ Z39.88-2004\&rft val fmt $=$ info\%3Aofi $\% 2 F f m t \% 3 A k e v \% 3 A m t x \% 3$ Abook\& rft.genre $=$ book\&rft.btitle $=$ World $\% 20$ urbanization $\% 20$ prospects

\%3A\%20The $\% 202007 \% 20$ revision\&rft.date $=2008 \&$ rfr id=info $\% 3$ Asid $\% 2$ Fwiley.com $\% 3$ AOnlineLibrary)

Wang, G. Y. 1991. Table of food ingredients (representative values in China). Beijing : People's Medical Publishing House [in Chinese]. (?url ver=Z39.88-2004\& rft val fmt $=$ info $\% 3$ Aofi $\% 2 \mathrm{Ffmt} \% 3 \mathrm{Akev} \% 3 \mathrm{Amtx} \% 3$ Abook\&rft.genre=book\& rft.btitle $=$ Table $\% 20$ of $\% 20$ food $\% 20$ ingredients $\% 20 \% 28$ representative $\% 20$ values $\% 20$ in $\% 20$ China $\% 29 \&$ rft.date $=1991 \&$ rft.aulast $=$ Wang\&rft.aufirst $=$ G. $\% 20 \mathrm{Y} . \&$ $\underline{\mathrm{rfr} \text { id }=\text { info } \% 3 \text { Asid } \% 2 \text { Fwiley.com } \% 3 \text { AOnlineLibrary) }}$

Warren-Rhodes, K. and A. Koenig. 2001. Escalating trends in the urban metabolism of Hong Kong: 1971-1997. AMBIO 30(7): 429-438.

PubMed (/resolve/reference/PMED?id=11795217), CAS (/resolve/reference /CAS?id=1:STN:280:DC\%2BD38\%2FmvFCkuw\%3D\%3D), Web of Science ${ }^{\circledR}$ Tin Cited: 34 (/resolve/reference/ISI?id=000172724300005) (?url_ver=Z39.88-2004\& rft_val_fmt $=$ info $\% 3$ Aofi $\% 2 F f m t ~ \% 3 A k e v \% 3 A m t x \% 3$ Ajournal\&rft.genre $=$ article $\&$ rft.jtitle $=$ AMBIO\& rft.atitle=Escalating $\% 20$ trends $\% 20$ in $\% 20$ the $\% 20$ urban $\% 20$ metabolism $\% 20$ of $\% 20$ Hong $\%$ $\% 3 \mathrm{~A} \% 201971 \% \mathrm{E} 2 \% 80 \% 931997 \&$ rft.volume $=30 \&$ rft.issue $=7 \&$ rft. spage $=429 \&$ rft.epage $=438 \&$ rft.date $=2001 \&$ rft.aulast $=$ Warren $\% \mathrm{E} 2 \% 80 \% 90$ Rhodes $\&$ rft.aufirst $=\mathrm{K} . \&$

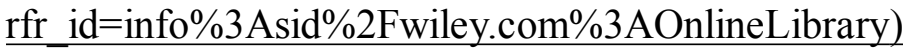

Wolman, A. 1965. The metabolism of cities. Scientific American 213(3): 179-190.

CrossRef (/resolve/reference/XREF?id=10.1038/scientificamerican0965-178), PubMe (/resolve/reference/PMED?id=14338520), CAS (/resolve/reference /CAS?id=1:STN:280:DyaF2M7ktlCiuw\%3D\%3D), Web of Science® Times Cited: (/resolve/reference/ISI?id=A19656770300012)

(?url ver $=$ Z39.88-2004\&

$\underline{\mathrm{rft} \text { val } \mathrm{fmt}=\mathrm{info} \% 3 \mathrm{Aofi} \% 2 \mathrm{Ffmt} \% 3 \mathrm{Akev} \% 3 \mathrm{Amtx} \% 3 \mathrm{Ajournal} \& \mathrm{rft} . \mathrm{genre}=\text { article } \&}$ rft.jtitle $=$ Scientific $\% 20$ American $\&$ rft.atitle $=$ The $\% 20$ metabolism $\% 20$ of $\% 20$ cities $\&$

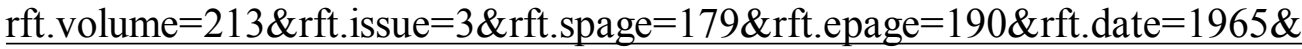


rft.aulast $=$ Wolman\&rft.aufirst $=$ A.\&

rfr id $=$ info $\% 3$ Asid $\% 2$ Fwiley.com $\% 3$ AOnlineLibrary)

Wong, J. 1998. Xiao-kang: Deng Xiaoping's socio-economic developing target for China. Journal of Contemporary China 7(17): 141-152.

CrossRef (/resolve/reference/XREF?id=10.1080/10670569808724309)

(?url_ver=Z39.88-2004\&

$\underline{\mathrm{rft} \_ \text {val fmt }=\text { info } \% 3 \mathrm{Aofi} \% 2 \mathrm{Ffmt} \% 3 \mathrm{Akev} \% 3 \mathrm{Amtx} \% 3 \mathrm{Ajournal} \& \mathrm{rft} . \mathrm{genre}=\text { article } \&}$ rft.jtitle $=$ Journal $\% 200 f \% 20$ Contemporary $\% 20$ China\&rft.atitle $=$ Xiao $\%$ E2\%80\%90kang \%3A $\% 20$ Deng $\% 20$ Xiaoping $\% 27 \mathrm{~s} \% 20$ socio $\%$ E2\%80

$\% 90$ economic $\% 20$ developing $\% 20$ target $\% 20$ for $\% 20$ China $\&$ rft.volume $=7 \& \mathrm{rft}$.issue $=17 \&$ rft.spage $=141 \&$ rft.epage $=152 \&$ rft.date $=1998 \&$ rft.aulast $=$ Wong\&rft.aufirst $=J . \&$ rfr $\mathrm{id}=$ info $\% 3$ Asid $\% 2$ Fwiley.com $\% 3$ AOnlineLibrary)

Xie, Y., Y. Mei, G. Tian, and X. Xing. 2005. Socio-economic driving forces of arable land conversion: A case study of Wuxian City, China. Global Environmental Change 15(3): 238-252.

CrossRef (/resolve/reference/XREF?id=10.1016/j.gloenvcha.2005.03.002), Web of Science ${ }^{\circledR}$ Times Cited: 33 (/resolve/reference/ISI?id $\left.=000231585500007\right)$ (?url ver $=$ Z39.88-2004\& rft val fmt $=$ info $\% 3$ Aofi $\% 2 F f m t \% 3 A k e v \% 3$ Amtx $\% 3$ Ajournal\&rft.genre $=$ article $\&$ rft.jtitle $=$ Global $\% 20$ Environmental $\% 20$ Change $\&$ rft.atitle $=$ Socio $\% \mathrm{E} 2 \% 80$ \%90economic $\% 20$ driving\%20forces $\% 20$ of $\% 20$ arable $\% 201$ and $\% 20$ conversion $\% 3 \mathrm{~A} \% 20 \mathrm{~A} \% 20$ case $\% 20$ study $\% 20$ of $\% 20 \mathrm{Wuxian} \% 20 \mathrm{City} \% 2 \mathrm{C} \% 20 \mathrm{China} \&$ rft.volume $=15 \&$ rft.issue $=3 \&$ rft. .spage $=238 \&$ rft.epage $=252 \&$ rft.date $=2005 \&$ rft.aulast $=$ Xie\&rft.aufirst $=$ Y.\&rfr $\mathrm{id}=$ info $\% 3$ Asid $\% 2$ Fwiley.com $\% 3$ AOnlineLibrary)

Xu, C. and G. Z. Gertner. 2008. Uncertainty and sensitivity analysis for models with correlated parameters. Reliability Engineering and System Safety 93(10): 1563-1573.

CrossRef (/resolve/reference/XREF?id=10.1016/j.ress.2007.06.003), Web of Science ${ }^{\circledR}$ Times Cited: 10 (/resolve/reference/ISI?id=000256985500017) (?url_ver $=$ Z39.88-2004\& $\underline{\mathrm{rft} \text { val } \mathrm{fmt}=\mathrm{info} \% 3 \mathrm{Aofi} \% 2 \mathrm{Ffmt} \% 3 \mathrm{Akev} \% 3 \mathrm{Amtx} \% 3 \mathrm{Ajournal} \& \mathrm{rft} . \mathrm{genre}=\text { article } \&}$ rft.jtitle $=$ Reliability $\% 20$ Engineering $\% 20$ and $\% 20$ System $\% 20$ Safety \& rft.atitle $=$ Uncertainty $\% 20$ and $\% 20$ sensitivity $\% 20$ analysis $\% 20$ for $\% 20$ models $\% 20 \mathrm{with} \% 20$ rft.volume $=93 \&$ rft.issue $=10 \&$ rft. .spage $=1563 \&$ rft.epage $=1573 \&$ rft.date $=2008 \&$

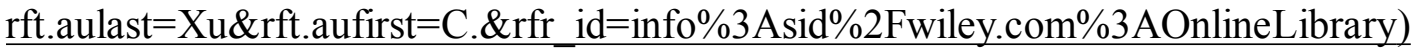

Xu, C. and G. Z. Gertner. 2011. Understanding and comparisons of different sampling approaches for the Fourier Amplitudes Sensitivity Test (FAST). Computational Statistics and Data Analysis 55(1): 184-198.

CrossRef (/resolve/reference/XREF?id=10.1016/j.csda.2010.06.028), Web of Science (/resolve/reference/ISI?id $=000283017900016)$

(?url ver $=$ Z39.88-2004\& $\underline{\mathrm{rft} \text { val } \mathrm{fmt}=\mathrm{info} \% 3 \mathrm{Aofi} \% 2 \mathrm{Ffmt} \% 3 \mathrm{Akev} \% 3 \mathrm{Amtx} \% 3 \mathrm{Ajournal} \& \mathrm{rft} . \mathrm{genre}=\text { article } \&}$ 
rft.jtitle $=$ Computational $\% 20$ Statistics $\% 20$ and $\% 20$ Data $\% 20$ Analysis \&

rft.atitle $=$ Understanding $\% 20$ and $\% 20$ comparisons $\% 20$ of $\% 20$ different $\% 20$ sampling $\% 20 \mathrm{ap}$ $\% 20 \% 28$ FAST $\% 29 \&$ rft.volume $=55 \&$ rft.issue $=1 \&$ rft.spage $=184 \&$ rft.epage $=198 \&$ rft.date $=2011 \&$ rft.aulast $=$ Xu\&rft.aufirst $=$ C. $\&$

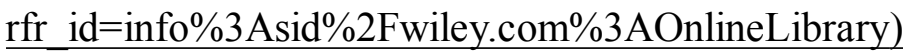

Yang, P., H. Y. Zhang, and X. Qiao. 2006. Discuss on improvement of phosphorus removal in urban sewage plant. China Environmental Protection Industry 1: 25-27.

Web of Science ${ }^{\circledR}$ Times Cited: 12 (/resolve/reference/ISI?id=000207069100005) (?url ver $=$ Z39.88-2004\&

rft_val_fmt $=$ info $\% 3$ Aofi $\% 2 F f m t \% 3 A k e v \% 3 A m t x \% 3$ Ajournal\&rft.genre $=$ article $\&$ rft.jtitle $=$ China $\% 20$ Environmental $\% 20$ Protection $\% 20$ Industry $\&$

rft.atitle=Discuss $\% 20 \mathrm{on} \% 20 \mathrm{improvement} \% 20 \mathrm{of} \% 20$ phosphorus $\% 20$ removal $\% 20 \mathrm{in} \% 20 \mathrm{c}$

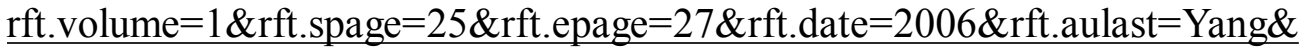

rft.aufirst=P.\&rfr $\mathrm{id}=$ info $\% 3$ Asid $\% 2$ Fwiley.com $\% 3$ AOnlineLibrary)

Zhai, F. Y., Y. N. He, G. S. Ma, Y. P. Li, Z. H. Wang, Y. S. Hu, L. Y. Zhao, C. H. Cui, Y. Li, and X. G. Yang. 2005. Study on the current status and trend of food consumption among Chinese population. Chinese Journal of Epidemiology 26(7): 485-488 [in Chinese, with English abstract.

PubMed (/resolve/reference/PMED?id=16334997)

(?url ver $=$ Z39.88-2004\&

rft val fmt $=$ info $\% 3$ Aofi $\% 2 F f m t \% 3 A k e v \% 3$ Amtx $\% 3$ Ajournal\&rft.genre $=$ article $\&$ rft.jtitle $=$ Chinese $\% 20$ Journal $\% 20$ of $\% 20$ Epidemiology \&

rft.atitle $=$ Study $\% 20$ on $\% 20$ the $\% 20$ current $\% 20$ status $\% 20$ and $\% 20$ trend $\% 20$ of $\% 20$ food $\% 2$

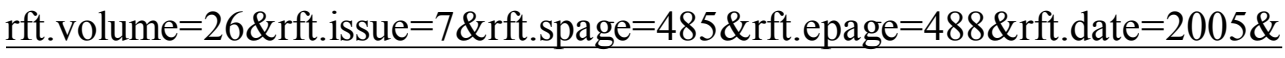
rft.aulast $=$ Zhai\&rft.aufirst $=$ F. $\% 20$ Y.\& $\underline{\mathrm{rfr} \text { id }=\text { info } \% 3 \mathrm{Asid} \% 2 \mathrm{Fwiley.com} \% 3 \mathrm{AOnlineLibrary)}}$

Zhang, G., Y. Zhao, J. Yang, W. Zhao, and Z. Gong. 2007. Urban soil environment issues and research progresses. Acta Pedologica Sinica 44(5): 925-933 [in Chinese, with English abstract.

CAS (/resolve/reference/CAS?id=1:CAS:528:DC\%2BD2sXhtlWnsb\%2FM) (?url_ver $=$ Z39.88-2004\&

$\underline{\text { rft val fmt }=\text { info } \% 3 \text { Aofi } \% 2 \mathrm{Ffmt} \% 3 \mathrm{Akev} \% 3 \mathrm{Amtx} \% 3 \mathrm{Ajournal} \& \mathrm{rft} . \mathrm{genre}=\text { article } \&}$ rft.jtitle $=$ Acta $\% 20$ Pedologica $\% 20$ Sinica \&

rft.atitle=Urban $\% 20$ soil $\% 20$ environment $\% 20$ issues $\% 20$ and $\% 20$ research $\% 20$ progresses $\&$ rft.volume $=44 \&$ rft.issue $=5 \&$ rft. .spage $=925 \&$ rft.epage $=933 \&$ rft.date $=2007 \&$

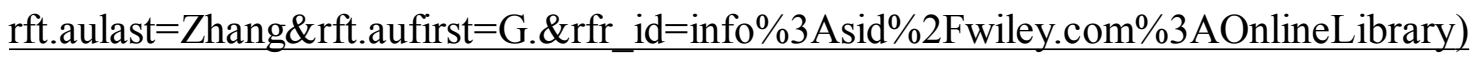

Zhou, H., Q. Ma, Z. Jiang, and W. Yu. 2009. Effect of different manure application rates on nutrition content and distribution in maize. Chinese Journal of Eco-Agriculture 17(4): 647-650 [in Chinese, with English abstract.

CrossRef (/resolve/reference/XREF?id=10.3724/SP.J.1011.2009.00647), CAS (/resolv /reference/CAS?id=1:CAS:528:DC\%2BD1MXpvFSju7o\%3D) 
(?url ver $=$ Z39.88-2004\&

rft_val_fmt $=$ info $\% 3$ Aofi $\% 2 \mathrm{Ffmt} \% 3 \mathrm{Akev} \% 3 \mathrm{Amtx} \% 3 \mathrm{Ajournal} \& \mathrm{rft} . \mathrm{genre}=$ article $\&$ rft.jtitle $=$ Chinese $\% 20$ Journal $\% 20$ of $\% 20$ Eco-Agriculture \& rft.atitle $=$ Effect $\% 20$ of $\% 20$ different $\% 20$ manure $\% 20$ application $\% 20$ rates $\% 20$ on $\% 20$ nutri $\underline{\text { rft. }}$ volume $=17 \&$ rft.issue $=4 \&$ rft.spage $=647 \&$ rft.epage $=650 \&$ rft.date $=2009 \&$ rft.aulast $=$ Zhou\&rft.aufirst $=$ H.\&rfr $\mathrm{id}=\mathrm{info} \% 3 \mathrm{Asid} \% 2 \mathrm{Fwiley.com} \% 3$ AOnlineLibrary)

\section{About the Authors}

Guilin Li is an assistant professor at the Institute of Urban Environment, Chinese Academy of Sciences (IUE, CAS) in Xiamen, China. Xuemei Bai is a professor at Fenner School of Environment and Society, Australian National University, Canberra, Australia. Shen Yu is a professor in the IUE, CAS in Xiamen, China. Yong-Guan Zhu is a professor and director of the IUE, CAS in Xiamen, China. Hua Zhang is an environmental engineer at Tetra Tech, Charleston, West Virginia, USA.

Get PDF (788K) (/doi/10.1111/j.1530-9290.2011.00402.x/pdf)

\section{More content like this}

Find more content:

- $\underline{\text { like this article (/advanced/search/results?articleDoi=10.1111/j.1530-9290.2011.00402.x\& }}$ $\underline{\text { scope }}=$ allContent\&start $=1 \&$ resultsPerPage $=20$ )

Find more content written by:

- Gui-Lin Li (/advanced/search/results?searchRowCriteria[0].queryString="Gui-Lin Li"\&searchRowCriteria[0].fieldName=author\&start=1\&resultsPerPage=20)

- Xuemei Bai (/advanced/search/results?searchRowCriteria[0].queryString="Xuemei Bai"\&searchRowCriteria[0].fieldName=author\&start=1\&resultsPerPage=20)

- Shen Yu (/advanced/search/results?searchRowCriteria[0].queryString="Shen Yu"\&searchRowCriteria[0].fieldName=author\&start=1\&resultsPerPage $=20$ )

- Hua Zhang (/advanced/search/results?searchRowCriteria[0].queryString="Hua Zhang"\&searchRowCriteria[0].fieldName=author\&start=1\&resultsPerPage=20)

- Yong-Guan Zhu (/advanced/search/results?searchRowCriteria[0].queryString="Yong-Guan Zhu"\&searchRowCriteria[0].fieldName=author\&start=1\&resultsPerPage=20)

- All Authors (/advanced/search/results?searchRowCriteria[0].queryString="Gui-Lin Li" "Xuemei Bai" "Shen Yu" "Hua Zhang" "Yong-Guan Zhu"\&searchRowCriteria[0].fieldName=author\& $\underline{\text { start }=1 \& \text { resultsPerPage }=20 \text { ) }}$ 